\section{REASENTAR UN HÁBITAT VULNERABLE. Teoría versus praxis}

Anne-Catherine Chardon ${ }^{1}$

\section{RESETTLING A VULNERABLE HABITAT. Theory against practice}

Anne-Catherine Chardon ${ }^{1}$

\section{Resumen}

Ante la vulnerabilidad de las poblaciones urbanas expuestas a amenazas naturales, los municipios colombianos tienen la obligación de plantear soluciones, entre otras, a través de procesos de reasentamiento que consisten en la adquisición por parte de la comunidad vulnerable, de un lugar de vida nuevo o "usado" en un sitio seguro desde el punto de vista físico-natural. Al estudiar los proyectos desarrollados hasta el momento, se observa una visión institucional sesgada y errónea del concepto de vulnerabilidad que lleva a unas políticas de reasentamiento que no tienen en cuenta al hábitat en su acepción más amplia, ni tampoco están orientadas hacia el mejoramiento integral de la calidad de vida de los pobladores. Por consiguiente, el presente escrito plantea, primero, una reflexión sobre los conceptos determi-

\section{Abstract}

Given the vulnerability of urban populations exposed to natural threats, Colombian city councils must find solutions through resettlement processes, so that vulnerable communities, from a physical-natural perspective, can acquire new or "used" land in a safe place. By analyzing projects developed up to now, there is a wrong and biased institutional idea of vulnerability, leading to resettlement policies that do not take the whole concept of habitat into consideration, nor are they oriented towards the improvement quality of life of dwellers. Therefore, this article puts forward a reflection on the critical concepts 
nantes en este tipo de procesos, antes de presentar y analizar experiencias de reasentamiento llevadas a cabo en la ciudad de Manizales (Colombia).

PALABRAS CLAVES: HÁBITAT, VULNERABILIDAD, REASENTAMIENTO, CALIDAD DE VIDA.

Fecha de recepción: 18.06.10

Fecha de aceptación: 15.10.10

1 Francia. Doctora en Geografía Universidad de Joseph Fourier Grenoble, Francia. Académica Universidad Nacional de Colombia. Correo electrónico: acchardon@unal.edu.co

18 revista invi № 70 / Noviembre 2010 / Volumen № 25: 17-75 of this kind of processes before presenting and analyzing resettlement experiences that are taking place in Manizales, Colombia.

KEYWORDS: HABITAT, VULNERABILITY, RESETTLEMENT, QUALITY OF LIFE
Received: 18.06 .10

Accepted: 15.10 .10

\footnotetext{
French. Ph.D. in Geography, Joseph Fourier University, Grenoble, France. Academic, National University of Colombia. Email: acchardon@unal.edu.co
}

ARTICLE: Resettling a vulnerable habitat. Theory against practice /Anne-Catherine Chardon 


\section{Introducción ${ }^{2}$}

El tríptico conformado por tres conceptos complejos como son el hábitat, la vulnerabilidad y el reasentamiento representa sin lugar a duda un objeto de reflexión muy interesante desde el ámbito urbano latinoamericano, puesto que efectivamente, rara vez se puede considerar un término sin acudir a los otros dos, visión que, además, importa ampliar con los conceptos de pobreza, calidad de vida y desarrollo.

Efectivamente, en el momento de analizar la vulnerabilidad de un asentamiento humano ante algún tipo de amenaza, lo que realmente se debe estudiar de manera sistémica, es el hábitat humano vulnerable, entendido en su acepción más amplia. Si en este contexto, la pobreza y la calidad de vida pueden representar factores de vulnerabilidad, es necesario matizar esta situación, puesto que los asentamientos urbanos vulnerables presentan también una gran riqueza en muchos aspectos.

Esta mirada integral de un contexto vulnerable obliga en el momento de plantear procesos de mitigación del riesgo, a seguir con esta misma inte-

2 El presente artículo presenta en su segunda parte, algunos resultados de una investigación llevada a cabo entre los años 2007 y 2009 sobre el tema "Procesos de reasentamiento de poblaciones urbanas vulnerables en contextos de amenazas naturales: modelos de análisis desde la complejidad del hábitat, el desarroIlo y la sostenibilidad", financiada por la Universidad Nacional de Colombia y COLCIENCIAS.

\section{Introduction ${ }^{2}$}

Habitat, vulnerability and resettlement are three complex concepts that, from a Latin American urban perspective, represent an interesting object of reflection, since it is not common to consider one term without taking the other two into account. This view should also be heightened by adding the concepts of poverty, quality of life and development.

Indeed, when it comes to analyzing the vulnerability of a human settlement against a threat, it is the vulnerable human habitat that should be systematically studied. In this context, if poverty and quality of life represent vulnerability, then it will be necessary to qualify that situation, as vulnerable urban settlements are rich in a series of aspects.

This comprehensive view should not be modified when planning risk reduction processes, as it enables addressing the problem as a whole, as well as dealing with the shortcomings and

2 The second part of this article presents the results of research "Resettlement Processes of Vulnerable Urban Populations Exposed to Natural Threats: Analysis Models from Habitat, Development and Sustainability Complexities" conducted from 2007 to 2009 and funded by the National University of Colombia and COLCIENCIAS. 
gralidad a fin de abarcar la problemática en su conjunto e intervenir sobre la totalidad de las falencias y fragilidades que caracterizan a una comunidad. Una de las actuaciones de intervención para disminuir el riesgo, son los programas de reasentamiento de población, política que, en el caso colombiano, ilustrará el discurso teórico más adelante.

\section{Habitar un hábitat vulnerable, reflexiones}

Al analizar las políticas de mitigación de la vulnerabilidad ante amenazas de origen natural en ámbitos urbanos latinoamericanos, se observan grandes falencias en las actuaciones, las cuales, de manera casi exclusiva, están orientadas hacia el campo físico-natural o físico-espacial, dejando a un lado factores fundamentales de vulnerabilidad pertenecientes a las dimensiones social, cultural, económica y financiera principalmente. Adicionalmente, las intervenciones llevadas a cabo no se caracterizan por una eficacia óptima, al contrario, con frecuencia están limitadas a acciones básicas, cuyo fin es la preservación de la vida y los bienes de los asentamientos vulnerables, sin ninguna otra pretensión. Gran parte de la explicación de esta situación está relacionada con una visión institucional muy sesgada y errónea del contexto de vulnerabilidad, al igual que a un desconocimiento del objeto vulnerable. Por consiguiente, importa fragility of a community. One of the initiatives for risk reduction is the program for population resettlement; in the Colombian case, this policy illustrates this theoretical approach.

\section{Inhabiting a Vulnerable Habitat, Reflections}

By analyzing vulnerability reduction policies against natural threats, in a Latin American urban context, there are shortcomings in the initiatives, which are oriented towards physical-natural or physical-spatial spheres, leaving aside essential factors of vulnerability related to social, cultural, economic and financial aspects. Additionally, these initiatives are not characterized by their effectiveness; they are only limited to basic actions aimed at preserving the life and goods of vulnerable settlements. This situation is related to a wrong and biased institutional idea of vulnerability, as well as to a lack of knowledge of the vulnerable object. As a result, it is important to think of these concepts to project and implement plans that reflect reality.

Concentrating on the concept of vulnerability involves first defining the vulnerable object. At urban scale, if the vulnerable object is regarded 
plantear una reflexión alrededor de estos temas, a fin de tener bases sólidas a partir de las cuales proyectar y ejecutar intervenciones holísticas ajustadas a la realidad.

Interesarse por el concepto de vulnerabilidad obliga primero a definir el objeto vulnerable. A la escala urbana, llevar a cabo un análisis en este campo representa un proceso metodológicamente alcanzable, si el objeto vulnerable es considerado como un Hábitat (entendido como hábitat humano urbano), concepto "articulador" para abordar la temática propuesta. Efectivamente, cuando se habla de la vulnerabilidad de una comunidad y de su posible reasentamiento como solución, lo que realmente está en juego es el Hábitat construido por esta comunidad y por lo tanto, no se puede limitar el proceso de reubicación a ella sola, sino que se debe contemplar el reasentamiento (y por supuesto mejoramiento) del Hábitat en sí.

\section{Habitar, hábitos, hábitat}

Los estudios consideran el concepto de Hábitat Humano desde una unidad espacial, el objeto "casa", pasando por la "vivienda" y finalmente, considerando la vivienda y su entorno como un contexto multidimensional, un sistema de vida ${ }^{3}$.

3 Florián, 2002; Fadda \& Jirón \& Bilbao, 2000; Franco, 1996 as Habitat (urban human habitat) -a concept that enables addressing the proposed subject matter- then carrying out an analysis in this field is a methodologically achievable process. In effect, when it comes to the vulnerability of a community and its possible resettlement, what is at stake is the habitat built by its dwellers; therefore, the relocating process should not only involve the community, but the resettlement (and improvement) of the habitat as well.

\section{Inhabiting, Habits, Habitat}

The present research identifies human habitat as a spatial unit; it starts with the "house" object, then with the "housing" object, and finally, it regards housing and its environment as a multidimensional context, a life system ${ }^{3}$.

Initially, it is important to point out that habitat should make inhabiting possible, a complex expression of "being" in the land that will be analyzed before exploring the concept of habitat.

Since the dynamic process of inhabiting is the result of the convergence of natural, social, economic, cultural, emotional and physical-

3 Florián, 2002; Fadda \& Jirón \& Bilbao, 2000; Franco, 1996. 
Inicialmente, importa precisar por si fuera necesario, que el Hábitat debe permitir Habitar, expresión muy compleja de ser y estar en la tierra que se va a analizar a continuación para luego permitir llegar al concepto de hábitat como tal.

La acción de habitar va mucho más allá de usar, ocupar, radicarse en, protegerse debajo de, puesto que el proceso dinámico de habitar resulta de la confluencia de distintos mundos: natural, social, económico, cultural, emocional, físico-espacial. Al habitar, el ser humano expresa que está construyendo su lugar, territorio y sistema de vida para poderse identificar con ellos, sentirlos propios y a la vez pertenecerles, enraizarse ahí y de igual forma proyectarse a partir de ahí. Por consiguiente, habitar no solamente tiene un significado espacial, sino multidimensional porque al habitar, el poblador establece conexiones con todos los elementos de su entorno, los utiliza, los transforma y por esto, habita a distintas escalas, al sentirse de ahí y participar de la transformación y el desarrollo de cada una de estas unidades.

El concepto de habitar está muy ligado al de construir en su acepción más amplia, es decir, mucho más allá de la construcción ingenieril, se trata de la edificación de un contexto, de un entorno de vida conforme a la manera de ser y las aspiraciones de su(s) constructor(es). Heidegger ${ }^{4}$ escribía a

$4 \quad$ Heidegger, 1994. spatial spheres; inhabiting means more than using, occupying, settling and finding protection. When inhabiting a determined space, humans express they are building their places, their territories and their life systems in order to feel identified with them; to feel they possess them and to feel they belong to those creations; to settle and project themselves. Consequently, inhabiting does not have a spatial meaning, but a multidimensional one, since the concept involves that the dweller forges connections with all the elements that surround him; he uses them, transforms them and as a consequence, he inhabits at different scales, since he feels he belongs there and takes part in the transformation and development of each of those units.

Inhabiting is linked to the whole concept of building, it goes beyond engineering, it is the construction of a context, a life environment that reflects the behavior and aspirations of its builders. According to Heidegger "Inhabiting is the purpose of building. Building is not only the means and the path for inhabiting, building is inhabiting in itself. (...) We do not inhabit because we build, but we build as long as we inhabit."

$4 \quad$ Heidegger, 1994. 
propósito "El habitar sería el fin que preside todo construir. Construir no es sólo medio y camino para el habitar, el construir es en sí mismo ya el habitar. (...) No habitamos porque construimos, sino que construimos y hemos construido en la medida en que habitamos".

Esta relación entre habitar y construir va en doble sentido, es decir, en el proceso de habitar, se está transformando, construyendo y se construye porque se está habitando, porque se quiere habitar. Así es, el ser humano, en el proceso de habitar, de crearse un entorno que se amolde a su forma de ser, sus necesidades, se dedica al ejercicio de la construcción, edificando su morada física tal como la necesita, como suele vivir los espacios y de igual manera, construye sus redes sociales, relacionándose con sus congéneres. Este proceso de entablar nexos con el entorno, de desempeñar un papel en la sociedad, asimismo se realiza por medio de los recorridos, de la movilidad que permite entrar en contacto con escalas espaciales mayores (el barrio, la ciudad), usos del suelo distintos al residencial (recreación, comercio, equipamientos de salud, educación), actividades laborales, etc. Como lo comenta Santos5, "No es posible habitar el mundo 'en abstracto' sin algún tipo de anclaje en el espacio y en el tiempo".

5 Santos, 2000.
This relationship between inhabiting and building has a double meaning, since in the process of inhabiting there are transformations and constructions; and building occurs because inhabiting is needed. In this sense, human beings, in the inhabiting process, in the creation of an environment that adapts to their behavior and needs, devote themselves to building; as they live the spaces, they construct the physical dwelling that meet their requirements. Similarly, they build social networks, establishing relationships with their peers. This process of playing a role in society is executed by mobility, enabling contact with major spatial scales (the neighborhood, the city); land uses other than residential (recreation, trade, health amenities, education); work activities; etc. As Santos points out, "Inhabiting the world in abstract' is not possible without some kind of anchorage in space and time."

By analyzing the relationship between building and inhabiting, it is clear that the second concept determines the first one, as building is intended for inhabiting, "(..) physical form on its own is not the determining factor of human satisfaction." ${ }^{\prime 6}$ However, this statement

Santos, 2000

Tarchópoulos Sierra \& Ceballos Ramos, 2003. 
Ahora bien, al analizar la relación conceptual en el otro sentido, desde el construir hacia el habitar, aparece de manera obvia que no se puede construir sin pensar en el habitar, puesto que se construye para habitar, "(...) la forma física por sí sola no es determinante de la satisfacción humana". Sin embargo, no siempre se contempla esta consideración y al respecto, Yori” escribe "La arquitectura y el urbanismo que tradicionalmente son guiados más por un "hacer" (en el sentido cotidiano del producirconstruir), poco tienen en cuenta el ser del hombre que ha de vivir en los espacios proyectados por estas ciencias para tal fin". Es así como en el momento de pensar en el construir, importa preguntarse entre otras preocupaciones, quién va a habitar, dónde quiere habitar, cómo quiere habitar, no solamente desde el punto de vista físico-espacial, sino también en los campos social, económico-laboral, de los equipamientos, la recreación, etc. Pues cómo se puede habitar si se tiene un techo pero debajo del cual se vive hacinado, sin empleo, sin acceso a la educación, la salud, con dificultades para poderse desplazar a otros sectores...

Esta particularidad, singularidad en la forma de vivir, convivir y relacionarse con su entorno, lleva a hablar del concepto de Hábitat Humano que, supuestamente, es el objeto que se habita. El concepto de Hábitat a pesar de que muchos posiblemente

Tarchópoulos Sierra y Ceballos Ramos, 2003.

7 Yori, 2007.

24 revista invi № 70 / Noviembre 2010 / Volumen № 25: 17-75 is not always considered; according to Yori "architecture and land planning, which have traditionally been focused on "making" (in the sense of producing-building), do not take the living of man into consideration, who is supposed to live in the spaces created by these disciplines." That is why building implies thinking about who is going to inhabit a place, where they want to inhabit and how they want to inhabit, not only considering physicalspatial aspects, but also social, labor-economic and recreational aspects, as well as those related to amenities. Then, how can inhabiting be possible if someone lives under overcrowded conditions, is out of work, has no access to education and health, and has problems to move to other areas?

This characteristic of living, coexisting relating to the environment leads to the concept of Human Habitat, which is, supposedly, the inhabited object. Despite being a thoroughly explored concept, Habitat is still an object of analysis, debate and contribution. The term Habitat was initially coined in the field of ecology to refer to the physical-spatial space where animal or vegetal species developed;

7 Yori, 2007. 
consideren que ya todo se haya dicho al respecto, es todavía objeto de análisis, debates, confrontación de disciplinas o aportes.

El término empezó a utilizarse en el campo de la ecología para referirse al espacio físico-natural donde se desenvuelve o desarrolla una especie animal o vegetal y todavía, ciertas profesiones o ciertos autores consideran que dicha definición también puede aplicarse al hábitat humano, agregándole un significado adicional, el de lugar. Es decir, definir el hábitat humano como una unidad espacial que el Hombre domesticó como lo explica Moreno Jaramillos: "El hábitat humano: construcción diagramática de una porción afectiva del paisaje físico ocupado por una población. Es necesario hablar de uso humano de un espacio material".

Distinta a la visión anterior, pero sin descartarla, la reflexión de Arias Vilas ${ }^{9}$ nos permite hacer una transición entre una orientación exclusivamente espacial o físico-natural que el autor califica (de manera errónea) de geográfica y un énfasis muy sesgado del hábitat humano que se suele encontrar en Europa y que corresponde al conjunto de las edificaciones y su distribución en el espacio: "El hábitat, término eminentemente geográfico. El concepto de hábitat ofrece dos posibilidades o acepciones: una referida a las condiciones de vida, al medio global en que vive el hombre; es una acepción si se

Moreno Jaramillo, 2002.

9 Arias Vilas, 1987 and there are still disciplines and authors that apply that concept to human habitat, adding the notion of place. Human habitat is defined as a spatial unit that was controlled by Man, in the words of Jaramillo, "Human habitat: Diagrammatic construction of an emotional part of the landscape used by a group of people. It should be referred to as the human use of material space."

Different to the previous statement, the view of Arias Vilas makes a transition from a physicalnatural approach to the biased concept of human habitat -common in Europe-based on the constructions and their spatial distribution; the author (wrongly) regards that switch as geographic: "Habitat offers two possibilities: one referred to life conditions, to the global environment in which man lives; it is a meaning that may be considered as ecologic. It is more interesting (...) the sense that refers to the use of land, to the geographic distribution of human settlements, to the human settling determined or influenced by environmental elements such as geography, climate or topography." This limited view of urban habitat is also found in France. Laborde,

Moreno Jaramillo, 2002.

Arias Vilas, 1987. 
quiere ecológica. Nos interesa más (...) la acepción que se refiere a la ocupación del territorio, es decir, a la disposición de los asentamientos humanos en el medio geográfico, al poblamiento humano, en todo caso, determinado o influido por condiciones ambientales de todo tipo: geológicas, climáticas, topográficas, etc”. Igual visión limitada del hábitat urbano se encuentra en Francia, como por ejemplo lo expresa Laborde en un subcapítulo de su escrito, titulado "Dynamique de l'habitat", refiriéndose exclusivamente al patrimonio residencial construido o planeado ${ }^{10}$ o tal como lo argumenta Rabinovich Behrend ${ }^{11}$ en su tesis doctoral, cuando se refiere al concepto de habitat groupé en el caso suizo.

En este proceso de ampliación del enfoque dado al concepto, se encuentran visiones donde además, el papel del ser humano empieza a cobrar fuerza, sin que, no obstante, el hábitat deje de ser visto como un soporte con el cual una sociedad entra en contacto, donde deja huellas y transforma elementos con fines de desarrollo. Este énfasis permite hablar de territorio humano y territorialidad cuyo significado hace referencia a los actos dinámicos de apropiación, transformación, "culturación" y antropomorfización del espacio, volviéndolo así territorio, es decir, un espacio con actores, dueños, defensores y dolientes con sentido de pertenencia hacia

10 Laborde, 1994.

11 Rabinovich Behrend, 1996. in his work "Dynamique de l'habitat", addresses the built or planned residential patrimony ${ }^{10}$; likewise, the doctoral thesis of Rabinovich Behrend ${ }^{11}$ refers to urban habitat when addressing the Swiss case of habitat groupé.

In this extension process of the approach given to the concept, there are views in which the role of human beings is becoming important. This does not alter the notion of habitat as the means that societies use to interact, to leave imprints and to transform elements for development purposes. This perspective deals with human territory and territoriality; the latter meaning refers to dynamic acts of appropriation, transformation, "culturalization" and anthropomorphization of space, turning it into territory; that it to say, a space with actors, owners, defenders and mourners with a sense of belonging to the spatial unit they recognize and feel identified with because they take part in its construction and development. García identifies territory as "a socialized and cultured space (...) with a sense of exclusivity." 12 At the same time, subjectivity and affectivity come into play, since

10 Laborde, 1994.

11 Rabinovich Behrend, 1996.

12 García, 1976. 
esta unidad espacial en la cual se reconocen, son reconocidos porque participan de su construcción y desarrollo. García ${ }^{12}$ habla del territorio como de "un espacio socializado y culturalizado (...) con sentido de exclusividad". A la vez, interviene gran parte de subjetividad y afectividad puesto que el territorio es también el fruto de una forma particular y propia de percibir el mundo y de vivir en él. Esta existencia de relaciones y emociones fuertes entre el ser humano y su entorno, como expresión de su forma de habitar y espacializar su modo de vida, es en parte lo que se aparenta a la topofilia que menciona Yori ${ }^{13}$.

Así es, la territorialidad es guiada por usos, costumbres, símbolos, afectos, búsquedas e intereses propios de sus actores, situación que permite que el concepto de hábitat empiece a perfilarse como un asunto singular, particular, único, por ser propio de sus habitantes, sus creadores y constructores. El Hábitat nace de hábitos y genera otros. Este aspecto antropológico es esencial, porque el Hábitat Humano es ante todo la expresión de una cultura, una identidad, es un sello propio tanto a nivel individual como a la escala de una comunidad.

Estas reflexiones y precisiones anteriores son fundamentales para la problemática del presente escrito, puesto que en un proceso de reasentamiento de poblaciones, se tiene que permitir estas actua-

12 García, 1976.

13 Yori, 2007. territory is also the result of a particular way to live and feel the environment. The relationships and emotions between human beings and their environment, as expression of how they live and spatialize their way of life, represent the topophilia described by Yori ${ }^{13}$.

In this sense, territoriality is determined by the uses, customs, symbols, affection, quests and interests of its actors. As a result, the concept of habitat takes shape as an independent topic because it belongs to its dwellers, creators and builders. Habitat is the product of habits; it also generates them. This anthropological aspect is essential, since Human Habitat is, above all, the expression of a determined culture; it is an identifying factor at individual and communal scale

These reflections and specifications are critical for developing the problem of this article, as resettlement processes, taking the original habitat into consideration, should enable territoriality in order to reconstruct habitat without causing trauma.

It seems evident that habitat does not exist as such; it is built around the vital space

13 Yori, 2007. 
ciones de territorialización, de expresión de la cultura para reconstruir hábitat sin que se generen traumas, teniendo en cuenta además el hábitat dejado, el hábitat de origen.

Ahora bien, parece cada vez más evidente que el hábitat no existe como tal, se construye alrededor del espacio de vida del ser humano, alrededor de lo que ahí posee, se caracteriza por una dimensión exclusivamente antropomórfica ${ }^{14}$. Por supuesto, al introducir el concepto de pertenencia, se llega paulatinamente al objeto vivienda que suele ser el contenedor más próximo donde o desde donde se tiene, tanto los bienes materiales como el patrimonio intangible, sin que por supuesto el hábitat se limite a la vivienda o habitáculo de vida, pero sí la vivienda como componente estructural principal del hábitat. Giraldo Isaza ${ }^{15}$ precisa que "El hábitat comprende la casa de las puertas hacia adentro, el entorno (de las puertas hacia fuera, barrio) y el contorno (ciudad). (...) De tal manera que el hábitat corresponde a la vivienda más el entorno". Es así como la vivienda representa un referente central a partir del cual el habitante se relaciona con su entorno y teje su mundo, su hábitat. Estas preocupaciones no se pueden comprender sin haber entendido que la vivienda no se limita al territorio comprendido entre los muros (la casa), sino que la vivienda también hace referencia al espacio

14 González Escobar, 2002

15 Giraldo Isaza, 1993 of human beings and it is characterized by its anthropomorphic scale ${ }^{14}$. Naturally, by introducing the concept of belonging, the housing object appears; it is the closest receptacle of goods and intangible patrimony. Then, habitat is not only limited to housing; however, housing is an essential element of habitat. Giraldo Isaza says that "Habitat comprises the house itself, the surroundings (the area outside the house, the neighborhood) and the limits (the city). (...) Therefore, habitat is the combination of housing and surroundings." 15 This is how housing is an important referent from which inhabitants interact with their surroundings and build their environment, their habitat. These concerns cannot be understood without comprehending that housing is not limited to the house; it refers to the space beyond the house itself, the surroundings for public use that are necessary for an acceptable daily life. For that reason, it is clear that housing, beyond its material value, is a critical element of habitat, mainly due to the experiences that take place at private and public levels. Everything goes and returns, this oscillating movement is the expression of the relationships that human beings establish with their environment before

14 González Escobar, 2002

15 Giraldo Isaza, 1993 
que empieza desde los muros hacia afuera, esto es el entorno próximo, en general de uso público, pero necesario a una vida cotidiana aceptable.

Por consiguiente, queda claro que la vivienda, más allá de la edificación como tal, representa un elemento fundamental del hábitat sobre todo desde las vivencias que ahí se dan y que desde ahí se generan con el entorno. Todo sale de ahí y vuelve ahí, este movimiento pendular es la expresión de las relaciones que el ser humano sale a entablar con su entorno para luego volver al nido. Las redes y la comunicación son elementos definitivamente esenciales en la creación y desarrollo de hábitat, nace, crece y se estructura a partir de ahí.

Sin pretender haber ofrecido un panorama exhaustivo del concepto de Hábitat, se presentó sin embargo unas visiones que permiten comprender que el hábitat es el resultante del encuentro cruzado entre cinco dimensiones principales: físico-natural, físico-espacial, socio-antropológica, económico-financiera y político-institucional que, consideradas de manera simultánea, conforman la dimensión ambiental en su acepción más extensa, obligando a una visión amplia de este objeto muy particular pero finalmente tan común, puesto que corresponde al contexto, sistema y proyección de vida de cada habitante. En este sentido, Chardon ${ }^{16}$ considera el hábitat, en el contexto urbano,

16 Chardon, 2008 returning to their respective places. The networks and communication are essential elements in the creation and development of habitat, which originates, evolves and gets structured from those components.

Despite not having developed the whole concept of habitat, this article presented some views that are useful to understand that habitat is the result of the convergence of physical-natural; physicalspatial; socio-anthropological; economicfinancial; and political-institutional aspects. Taken altogether, these spheres compose the environmental dimension in its wider sense; it is then required an insight into this aspect that is particular but common, as it is the life context, system and projection of each dweller. In this sense, Chardon regards habitat, from an urban perspective, as "the bio-physical-eco-sociospatialsystem, that is to say, a system whose components are the urban space, its dwellers (characterized by context; social, economic, historical and cultural processes; movements and forms of communication), the physicalspatial context representing the natural environment, the political-institutional context and relationships representing the links among these elements." 16 Additionally, it

16 Chardon, 2008 
"como un bio-físico-eco-socio-espaciosistema, es decir, un sistema cuyos componentes son el espacio urbano, sus ocupantes (caracterizados por un contexto, procesos sociales, económicos, históricos y culturales, recorridos y modos de comunicación), el entorno natural como físico-espacial, el contexto político-institucional y las relaciones como vínculos que estos elementos tejen entre sí”. Además, importa comentar que el Hábitat es la expresión de las dinámicas, nexos y redes que el ser humano establece con su entorno (sobre todo humano, envuelto en un tejido social seguro, firme y estable), por esto, debe permitir vivir en un territorio con significado, donde los habitantes más allá de estar, puedan ser, lo que deja entender que el hábitat está cargado de una fuerte dosis de subjetividad, producto de afectos, percepciones y símbolos propios de cada habitante, cada comunidad. Asimismo, el hábitat, por supuesto, tiene que propiciar las condiciones necesarias para el habitar, es decir, más que ocupar un lugar, habitarlo, apropiarse de él, transformarlo y acondicionar su entorno de vida con el fin de buscar optimizar sus condiciones y nivel de vida, en un contexto legal, seguro y sostenible.

Esta visión multidimensional del Hábitat deja entender que en el momento de analizar su vulnerabilidad, el enfoque del estudio también tendrá que ser integral, con el fin de reflejar plenamente la realidad. is worth noting that Habitat is the expression of dynamics, links and networks that human beings establish with their environment (a human environment, covered by a safe, strong and stable social fabric). That is why habitat should involve living in a meaning ful territory, where dwellers, beyond inhabiting, would be able to live freely. It is understood, then, that habitat, due to affection, perceptions and symbols of each dweller and community, has elements of subjectivity. In addition, habitat should offer proper conditions for inhabiting; it means more than using, dwelling, transforming and taking possession of a place and adapting its life environment in order to improve its condition and standards of living in a legal, safe and sustainable context.

This multidimensional view of Habitat suggests that, when analyzing its vulnerability, the approach to the research should be comprehensive as well, with the purpose of reflecting reality.

\section{Being Vulnerable, a Complex Matter}

In relation to the proposed subject matter, it is indispensable to reflect on the concept of 


\section{Ser vulnerable, un asunto complejo}

Con relación a la temática planteada, es imprescindible reflexionar sobre el concepto de vulnerabilidad, ya que los procesos de reasentamiento pretenden mitigarla, por consiguiente si el fin es solucionar una situación considerada crítica, importa conocer muy bien cada una de sus dimensiones y alcances para poder actuar sobre ella en todos los frentes. El tema de la vulnerabilidad de las sociedades urbanas expuestas a amenazas de origen natural pertenece en la actualidad al conjunto de las temáticas complejas, ya que corresponde a un sistema de factores multidisciplinares, lo cual dificulta tanto la formulación de la problemática, como luego su resolución. El problema se complejiza aún más en los países en desarrollo, donde los factores no estructurales y poco cuantificables son los principales agentes de la creación de una situación vulnerable. Dicha visión resulta de una evolución en las formas de abordar la temática, desde los planteamientos en las ciencias sociales de Quarantelli ${ }^{17}$ y Drabeck ${ }^{18}$ que empezaron a relacionar la percep-

17 Quarantelli, 1978.

18 Drabeck, 1986. vulnerability, as resettlement processes are thought to reduce it. Therefore, if the goal is to solve a critical situation, it is important to know each of its scales and effects well to act on them. The vulnerability of urban societies exposed to natural threats belongs today to a group of complex topics, as it is a system of multidisciplinary factors that makes the formulation and solution of the subject matter difficult. The problem gets even more complex in developing countries, where non structural and difficult to quantify factors are the main agents involved in the creation of a vulnerable situation. Such view is the result of the evolution of ways to address the subject matter, from the approaches in the field of social sciences made by Quarantelli ${ }^{17}$ and Drabeck ${ }^{18}$, who began to associate perception with disaster; the global oriented research of Anderson and Woodrow ${ }^{19}$ and Cannon ${ }^{20}$; to the contribution of Ratick, who theorizes about the role of exposition, resistance, resilience, recovery, learning and adaptation in the creation of vulnerability ${ }^{21}$, or 
ción con el desastre, pasando por los estudios con enfoque global de Anderson y Woodrow ${ }^{19}$ y Cannon ${ }^{20}$, para llegar al aporte de Ratick ${ }^{21}$, que plantea el papel de la exposición, resistencia, resiliencia, recuperación, aprendizaje y adaptación en la creación de vulnerabilidad o al modelo de "presión y liberación” propuesto por Blaikie et al. ${ }^{22}$

Para el presente escrito, se considera que la vulnerabilidad corresponde a la probabilidad (es factible a priori, pero no seguro) de que un sujeto o elemento expuesto a una amenaza natural, tecnológica, antrópica o socio-natural, sufra daños y pérdidas humanas como materiales en el momento del impacto del fenómeno, teniendo además dificultad en recuperarse de ello, a corto, mediano o largo plazo. Lo que significa que la vulnerabilidad se considera antes, durante y después del evento. Esto implica que la vulnerabilidad también expresa la ineptitud en anticipar, la inflexibilidad del elemento expuesto, su incapacidad en resistir o absorber el impacto (resistencia) y adaptarse a los cambios de toda índole que éste genera a fin de recuperarse y restablecer sus medios de vida (resiliencia) ${ }^{23}$.

La vulnerabilidad resulta del funcionamiento de un sistema complejo dinámico generado por pro-

19 Anderson y Woodrow, 1989.

20 Cannon, 1991.

21 Ratick, 1984

22 Blaikie et al., 1996.

23 Chardon 2002, 2008. the "pressure and release" model proposed by Blaikie et $a^{22}$.

In this article, vulnerability is regarded as the probability of a subject or element exposed to a natural, technological, anthropic or socionatural threat suffering damage, as well as human and material losses at the moment of impact of the phenomenon, considering also the difficulty of the recovery process in the short, mid and long term. This means that vulnerability is considered before, during and after the event. Then, vulnerability implies inappropriate prevention measures, the inflexibility of the exposed element, the incapacity to resist or absorb the impact (resistance) and the adaptation to any kind of changes in order to recover and reestablish the means of living (resilience) ${ }^{23}$.

Vulnerability is the result of the functioning of a complex dynamic system generated by processes that act on vulnerability factors, which belong to physical-natural, ecological, social, economic, physical-spatial, territorial

22 Blaikie et al., 1996.

23 Chardon, 2002, 2008. 
cesos que intervienen sobre factores de vulnerabilidad, los cuales pertenecen a campos físiconaturales, ecológicos, sociales, económicos, físicoespaciales, territoriales (uso del suelo, planeación y políticas territoriales), tecnológicos, culturales, educativos, funcionales, político-institucionales y administrativos o coyunturales principalmente. Esto deja entender que no existen vulnerabilidades pertenecientes a campos específicos, sino que la vulnerabilidad es una sola, dependiendo eso sí de una sinergia entre factores distintos.

En el caso de los procesos de reasentamiento, importa analizar muy bien cuáles son los factores de vulnerabilidad que llevaron a su planteamiento, a fin de que dichos procesos permitan influir sobre estas fuentes de vulnerabilidad y logren mitigarlas, en caso contrario, con frecuencia, los traslados poblacionales se vuelven generadores de nuevas situaciones de vulnerabilidad.

\section{Reasentar no es solamente trasladar}

Tal como se ilustrará más adelante, en la práctica, el concepto de reasentamiento como herramienta de mitigación de la vulnerabilidad, se contempla y aplica con pocas consideraciones y finalmente muy a la ligera. (use of land, planning and territorial policies), technological, cultural, educational, functional, political-institutional and administrative fields. It is understood that there are no vulnerability belonging to specific spheres, there is only one vulnerability; it depends on synergy among a series of factors.

In the case of resettlement processes, it is important to analyze the vulnerability factors that led to the implementation of this plan, so that these initiatives have influence on the sources of vulnerability and succeed in reducing them; otherwise, displacements may generate new conditions of vulnerability.

\section{Resettling does not only Mean Moving}

Resettlement, as a reduction mechanism of vulnerability, is not properly analyzed and its implementation is not taken seriously.

To debate on resettlement, it is important to reflect on the meaning of the verbs "to settle" and "settling" in a human context, which refer to occupying an area; however, this action has a special connotation that is related to security, strength, permanence and durability in time. 
Para hablar de re-asentamiento, importa reflexionar sobre el significado de los verbos "asentar" y "asentarse" en el contexto humano, los cuales por supuesto hacen referencia al hecho de establecer o establecerse en un sitio, pero con una connotación particular, esto es la seguridad, la firmeza, la permanencia y durabilidad en el tiempo. Esta permanencia lleva a comentar que el hecho de asentarse no es repentino sino que resulta de un proceso tanto espacial o físico-espacial como social, cultural, de identidad, económico, puesto que corresponde a la fundación de un lugar, de una comunidad, de un asentamiento y finalmente de un hábitat con sentido de arraigo.

El concepto de reasentamiento es sobre todo objeto de reflexión desde la práctica y es así como instituciones internacionales y como el Banco Mundial y el Banco Interamericano de Desarrollo que han participado de la financiación de numerosos proyectos de desalojo-desplazamiento, reasentamiento en los países de sus intereses, ponen ciertas condiciones a su participación, exigiendo que los procesos no se limiten a los aspectos físicos, sino que también abarquen dimensiones sociales, culturales y económicas, entre otras, en pro del desarrollo sostenido en el tiempo de la comunidad afectada $^{24}$. Por el momento, a nivel internacional, la visión institucional es más técnica que conceptual, pero sin embargo trata de ser amplia.

24 Partridge, 2000.
This notion of permanence implies that settling is not a rash decision, but is the result of a physical-spatial, social, cultural, identity and economic process, as it involves the foundation of a place, a community, a settlement and finally, habitat with a sense of belonging.

From a practical perspective, resettlement is an object of reflection. That is why international institutions such as the World Bank and the Inter-American Development Bank have funded a series of eviction-displacement and resettlement projects in countries that are of the interest of these organizations. They attach conditions, suggesting that the processes should not be limited to physical aspects, but also to social, cultural and economic aspects in order to favor the sustained development of the affected community ${ }^{24}$. At international level, the institutional view is more technical than conceptual; however, it is broadening its approach.

As an essential complement to this perspective, authors with reflection-oriented interests -that might be put into practice-give their opinion about resettlement; there are contributions ranging from the "simple" search for safety, to

24 Partridge, 2000. 
Como complemento esencial a este enfoque dado por la experiencia in situ, otros autores con intereses más orientados hacia la reflexión que luego pueda llevarse a la práctica, se han expresado sobre la temática del reasentamiento y se encuentran aportes desde la "simple" búsqueda de la seguridad hasta una visión compleja y multidimensional del concepto.

Así, Duque Botero ${ }^{25}$ considera el proceso de reasentar como la herramienta más efectiva para reducir la vulnerabilidad de las personas vulnerables ante eventos naturales o resolver los problemas de las comunidades que ya han sido damnificadas, pero no entrega detalles sobre las modalidades o condiciones que debe cumplir el procedimiento. Esta visión se asemeja a la posición de muchas autoridades locales, que limitan el objetivo de un proceso de reasentamiento a una operación de "salvar vidas y bienes".

Luego, se encuentran enfoques que empiezan a contemplar aspectos humanos en los proyectos de traslado, insistiendo en los cambios que se pueden generar, dejando entender que proteger la vida no es suficiente, también importa la calidad de vida, la cual no se limita al objeto casa. Al respecto, Robles Joya ${ }^{26}$ empieza a dar detalles de los aspectos humanos por contemplar, "Es preciso señalar que los procesos de reasentamiento no sólo se deben li-

25 Duque Botero, 2006.

26 Robles Joya, 2008. a complex and multidimensional view of the concept.

Duque Botero ${ }^{25}$ regards resettlement as the most effective mechanism for both reducing vulnerability of vulnerable people against natural threats, and for solving the problems of affected communities. However, the initiative does not give details about its conditions and procedures. This view is similar to that of local authorities, who see resettling as a process aimed at "saving lives and goods."

There are also approaches that consider the human aspects of resettlement, stressing the changes the process may produce, and pointing out that life quality - which is not only limited to the house object- is as important as protecting life. Robles Joya gives details about the human aspects to consider; "It is worth noting that resettlement processes should not only be aimed at reducing the physical condition of settlements, but also at improving the life condition of people and ensure their integration into the city. (...) Resettlement is also the revalorization of communal sense, human values, cultural ways of production,

25 Duque Botero, 2006. 
mitar a mitigar las condiciones físicas de los asentamientos, sino que deben también asumir de forma integral el mejoramiento de las condiciones de vida de la población y asegurar su inclusión en la ciudad. (...) El reasentamiento es también la recuperación del sentido comunitario, el valor humano, las formas culturales de producción y, sobre todo, de la esperanza de vida”. Más allá de la recuperación de la esperanza de vida, posiblemente se puede pretender volver a tener esperanzas en la vida.

Poco a poco, estas reflexiones permiten orientar el discurso hacia una visión cada vez más holística de lo que, en teoría, tendría que ser un proceso de reasentamiento. Sin embargo, hasta el momento, ha faltado hacer referencia a un término fundamental y obligatoriamente asociado al reasentamiento, es decir, el concepto de hábitat, el cual se menciona en la definición de Hurtado Isaza ${ }^{27}$ cuando escribe "[El reasentamiento es]...una experiencia de vida que involucra la transformación de la cotidianidad, a partir de un traslado poblacional definitivo, fuera del entorno de permanencia original, cuyo propósito es el mejoramiento de la calidad de vida y, por ende, la construcción o consolidación de un hábitat digno". Orozco Bermúdez y Guerrero Carvajal ${ }^{28}$ van aún más allá y recuerdan las condiciones de hábitat de origen y la obligación de llegar a un hábitat de des-

27 Hurtado Isaza, 2010.

28 Orozco Bermúdez y Guerrero Carvajal, 2008. and, most important, life expectancy ${ }^{26}$." Beyond the revalorization of life expectancy, it may be possible to have expectations in life again.

These reflections deal with the discussion from a holistic perspective of what a resettlement process should be. However, the fundamental concept of habitat, unavoidably linked to resettlement, has not been addressed yet. This notion is mentioned by Hurtado Isaza: "[Resettlement is] ... a life experience that involves the transformation of daily life, considering a definitive displacement outside the original area of permanence, which goal is the improvement of life quality and the construction of decent habitat ${ }^{27}$." Orozco Bermúdez and Guerrero Carvajal ${ }^{28}$ think of the conditions of the original habitat and the need of reaching destination habitat, properly equipped and built by concerted action of dwellers.

Then, resettlement programs are the reproduction of habitat that involves a certain degree of distress. If these initiatives do not consider multisectoral approaches, they risk

26 Robles Joya, 2008.

27 Hurtado Isaza, 2010

28 Orozco Bermúdez \& Guerrero Carvajal, 2008. 
tino con mejores características y sobre todo construido por acciones concertadas de sus pobladores.

Se entenderá entonces que los programas de reasentamiento representan un contexto de re-creación de hábitat muy particular que por supuesto no se desarrolla sin cambios dolorosos y, si no se lleva a cabo por medio de un trabajo multisectorial, se corre el riesgo de pasar de una marginalidad a otra, por mala gestión por parte de las autoridades.

Finalmente, después de estos distintos y complementarios planteamientos, se propone para el presente escrito, una conceptualización del reasentamiento también inspirada de la propuesta que realiza Chardon ${ }^{29}$.

Entonces, desde el punto de vista conceptual, el reasentamiento de poblaciones urbanas vulnerables a amenazas naturales se puede contemplar como un simple ejercicio de traslado de población, esto es un reasentamiento espacial, hasta la creación de un nuevo territorio o real hábitat de vida fuera del hábitat de origen en el marco de una política de reordenamiento de la ciudad. Es esta última acepción la más interesante y única válida, puesto que demuestra una visión sistémica de la situación. Efectivamente, el proceso de reasentamiento es ante todo humano (aspecto que no se puede perder de vista) y, a través de cambios y transformaciones en múltiples ámbitos, debe llevar a unas

29 Chardon, 2010 replacing a marginal situation by another, due to mismanagement of authorities.

This article, after putting forward these complementary opinions, proposes a conceptualization of resettlement based on the approach of Chardon ${ }^{29}$.

From a conceptual perspective, the resettlement of urban populations exposed to natural threats corresponds to the displacement of people, to a spatial resettlement until new habitat is created within the framework of a city reorganization policy, being this restructuring exercise an interesting element, as it shows a systematic approach to the problem. In effect, resettling is, above all, a human process (an aspect that cannot be eluded) that, through modifications and transformations in a series of areas, should involve offering proper and sustainable individual and communal habitat conditions, as its goal to restore and improve daily life, the environment and life quality of the people this program is intended to help. First, resettlement should consider physical-natural elements and find safe spatial conditions; however, as the goal of the plan is to influence on the sustainable development of a community, the initiatives

29 Chardon, 2010. 
condiciones de hábitat individuales como colectivas óptimas y sustentadas en el tiempo, ya que su fin es por lo menos restaurar pero sobre todo mejorar en su conjunto la cotidianidad, el entorno y calidad de vida de la población objeto del programa. Inicialmente, se tiene que pensar con relación al contexto físico-natural, buscando condiciones espaciales seguras, pero las actuaciones también tienen que llevarse a cabo en ámbitos estructurales como no-estructurales, internos o externos a la comunidad, es decir, en los campos social, cultural, económico, financiero, físico-espacial, jurídico, etc., puesto que se trata de participar del desarrollo, además sostenible, de una comunidad.

Reasentar poblaciones corresponde a construirles y con ellas (la participación de la comunidad desde la reflexión, planificación, diseño y ejecución es fundamental), un nuevo espacio de vida que ellas tienen que sentir como territorio de vida, es decir un espacio habitable, amigable, confortable, donde uno reconoce y siente el lugar del cual, además, uno se puede apropiar, al cual se puede arraigar y finalmente ser ahí un actor reconocido. Pues, la temática representa un problema político, alrededor del cual tiene que trabajar toda la colectividad y comunidad concernida, a fin de llegar a políticas y decisiones negociadas. Aun si los procesos son inicialmente involuntarios, con frecuencia no deseados por los pobladores, la participación activa de ellos permite un mejor nivel de aceptación y adaptación, a fin de que los programas respondan a su forma de vivir, should also act on structural, as well as non structural aspects that may, or may not belong to the community, such as social, cultural, economic, financial, physical-spatial and legal aspects.

Resettling means building a new space for people (whose involvement in its conception, planning, design and development is essential), a place they should fell as their life territory, an inhabitable, restful and comfortable place they know and feel, a place where they can settle and become active protagonists. This subject matter represents a political dilemma, as there are groups of people and communities involved in the problem in order reach decisions and define policies. Even if the processes are involuntary and often undesired by dwellers, their active participation will increase acceptation and adaptation levels, therefore, the programs will reflect their way of life, habits and culture and not imposed models that do not match their needs and daily activities.

Additionally, a resettlement process should contemplate measures aimed at controlling and defining the use of the vulnerable land that will be uninhabited, with the purpose of avoiding the return of the former dwellers and the establishment of a new settlement. 
sus hábitos, su cultura y no a modelos impuestos y lejos de su cotidianidad y necesidad.

Importa agregar que un proceso de reasentamiento de igual manera tiene que contemplar medidas hacia los lotes peligrosos que se van a desocupar, tanto desde el punto de vista de la tenencia legal como de los futuros usos de estos lotes y del control sobre ellos, a fin de evitar el regreso de los antiguos ocupantes o el establecimiento de nuevos asentamientos.

Se entiende entonces que los proyectos de reasentamiento tienen que responder de manera holística y definitiva a situaciones complejas, tanto individuales como colectivas y por lo tanto, tienen que ir mucho más allá de la simple búsqueda de un techo seguro. Los procesos implican un alto costo social, económico, cultural, político, al igual que grandes impactos físico-territoriales tanto en el hábitat de origen como en el sector de destino. Esto podría significar la vivencia de trastornos y alteraciones en la cotidianidad de los pobladores, pero el reto de un programa de reasentamiento consiste precisamente en prever todas estas implicaciones posibles y actuar de tal manera que el resultado consista en observar un desarrollo continuo de la comunidad reasentada.

Por consiguiente, la filosofía de este tipo de intervención es, en parte, intervenir sobre todas las expresiones de pobreza de una población, como sus carencias, sus fragilidades en todos los ámbitos,
It is understood, then, that resettlement projects should give a definitive and holistic answer to complex individual or communal situations; therefore, these solutions should mean more than finding a safe place to live in. These processes imply social, economic, cultural and political consequences, as well as physical-territorial impact on the original and destination habitat. This situation may interrupt or alter the daily life of dwellers; nevertheless, the challenge of a resettlement process is to predict the previously mentioned consequences and operate effectively so that the result is the sustainable development of the resettled community.

As a result, the aim of this kind of intervention is to act on each expression of poverty of a community, since poverty, as wealth, is not only related to economic or financial aspects, but to individual or collective needs that are not met at any scale (be it for the lack of resources or the incapacity to produce it); poverty may be considered as a relative and subjective life quality indicator, condition that should improve the resettlement process.

In the opinion of a non-expert, it is important to consider the perception of the dweller about his own poverty condition, about how he feels and experiences his needs. 
puesto que la pobreza, al igual que la riqueza, no es solamente económica o financiera, corresponde a necesidades sufridas de manera negativa individual o colectivamente en cualquier dimensión (tanto por falta del recurso como tal, como por incapacidad de producirlo) y puede ser considerada como un indicador subjetivo y relativo de la calidad de vida, condición que debe tender a mejorar un proceso de reasentamiento.

Es evidente que fuera del ojo del supuesto especialista, importa tener en cuenta la percepción del morador sobre su propia pobreza, las necesidades que él realmente siente y vive.

Ahora bien, después de estas reflexiones fundamentales para entender el contexto conceptual en el cual se debe enmarcar el reasentamiento de un hábitat vulnerable, se van a presentar proyectos concretos llevados a cabo en Manizales (Colombia) que permitirán ilustrar los aciertos y desaciertos de este tipo de intervención.

\section{Reasentamiento, la realidad está lejos de la teoría...}

El reasentamiento representa en Colombia una opción de mitigación del riesgo utilizada en situaciones de imposibilidad de intervención in situ sobre
This article, after presenting these reflections, fundamental to understand the conceptual context of resettling a vulnerable habitat, presents projects implemented in Manizales (Colombia), illustrating the contributions and mistakes of this kind of intervention.

\section{Resettlement, Reality is Far from Theory...}

In Colombia, resettlement is a mechanism for risk reduction used in situations where intervention is not possible because of the dangerousness of the area; the dweller, then, is free to choose between social housing programs in new, safe zones, or buy a pre-owned house that has been previously checked by authorities.

Despite not having policies for drawing up and implementing resettlement plans, the Colombian State has the Social Interest Housing $(\mathrm{SIH})$, a project that share characteristics with resettlement initiatives; the goals and regulations of SIH can be consulted in Ceballos Ramos $\mathrm{ed}^{30}$. The approach of the State to this problem is illustrated in the National

30 Ceballos Ramos ed., 2008. 
la vulnerabilidad, por razones de alta peligrosidad y entonces el poblador puede optar por programas de vivienda de interés social nuevos en sectores seguros o elegir la compra de una vivienda usada, una vez las autoridades hayan revisado el inmueble.

El Estado colombiano no cuenta actualmente con una política reglamentaria específica para formular y ejecutar planes de reasentamiento, los cuales se asimilan a proyectos de Vivienda de Interés Social (VIS) cuyos propósitos y normativas pueden consultarse en Ceballos Ramos ed ${ }^{30}$. La filosofía general del Estado ante esta temática puede verse reflejada en ciertos apartes de la Constitución Nacional ${ }^{31}$ como 1- el amparo de la familia (Art.5) y 2- el derecho a la vivienda en condiciones de dignidad, es decir, en condiciones materiales y espirituales de existencia que permitan vivir con calidad y tener un espacio para el libre desarrollo de la personalidad (sent. C-575/92. Art. 51). Pero, si esta visión teórica macro y de referencia nacional deja entender que el Estado se preocupa por el bienestar de la población y vigila que se respete, las orientaciones sin embargo quedan demasiado generales y sobre todo sin obligaciones metodológicas (se obliga al "qué" sin orientar sobre el "cómo"), situación que finalmente, en la realidad, puede dar pie a aplicaciones muy distintas desde el punto de vista cua-

30 Ceballos Ramos ed., 2008.

31 República de Colombia, 1991.
Constitution ${ }^{31}$, namely, the protection of family (Art. 5); and the right to decent housing, that is to say, the access to material and spiritual conditions of existence that ensure living with quality and the space to the free development of personality (sent. C-575/92. Art. 51). However, if this theoretical view of national reference implies that the State cares for its citizens and enforces welfare laws, then its approach will be general and will not have methodological obligations (it will address the "what" and not the "how" of the problem). This situation may generate completely different, but legal, qualitative application. Additionally, although the constitutional framework suggests that resettlement in Colombia is the result of social and humanist concern which goal is improving the life quality of vulnerable population, as well as promoting their participation in resettlement processes, this is not always true, and there are many things to do about that.

Through a comparative analysis of the resettlement processes that have been taking place in Manizales since the eighties, this article contrasts a desired theory and an imposed practice. Likewise, three different

31 The Republic of Colombia, 1991. 
litativo, pero todas legalmente válidas. Además, a pesar de que el marco constitucional deje suponer que el reasentamiento en Colombia sería fruto de una real preocupación social y humanista que buscaría el mejoramiento de la calidad de vida de la población objeto de estudio y su participación en los procesos, no siempre es así y mucho falta.

A través de un análisis comparativo de los procesos de reasentamiento desarrollados en Manizales a partir de los años 80, se observará la distancia entre una teoría deseada y una práctica impuesta. Se compararán tres modalidades de reasentamiento donde la visión del especialista se mezclará con los comentarios de los pobladores reasentados, obtenidos a través de cerca de seiscientas encuestas llevadas a cabo en nueve urbanizaciones. Con una representatividad entre un $30 \%$ y un $50 \%$, dependiendo del sector, la encuesta contó con 104 preguntas repartidas en temáticas que abarcaban desde el hábitat de origen hacia el de destino, a la escala del barrio como de la unidad residencial, contemplando los ámbitos multidimensionales que conforman el hábitat humano, al igual que la gestión de los procesos de reasentamiento como tales. El perfil (muy representativo de la población de interés) de las personas entrevistadas al azar en su casa o sector de residencia actual, correspondió en su mayoría a personas adultas (83\%) y amas de casa (61\%), cuyo nivel escolar se repartía entre primaria incompleta y bachillerato y en el hogar de las cuales, el ingreso mensual era muy débil, puesto que forms of resettlement are compared, where the approach of the specialist is collated with the opinions of relocated dwellers -information collected after conducting 600 surveys in nine towns. Representing between 30 and 50\% of the population, depending on the studied area, the survey was composed of 104 questions divided into topics such as the original habitat, the destination habitat, the scale of the neighborhood as a residential unit, the multidimensional aspects that compose human habitat, and the management of resettlement processes. The background of respondents (representative of the target population) -chosen at random- is as follows: adults (83\%), housewives whose level of education ranged from incomplete primary education to secondary education (61\%), minimum wage (250 USD) per household (54\%), and less than minimum wage per household (28\%).

\section{Resettlement, from Habitat to Habitat, Practical Application in Manizales}

Manizales is an intermediate Andean city (380,000 inhabitants); it has a rough topography and poorly compacted volcanic 
en un 54\% equivalía al salario mínimo mensual de 250 USD, siendo a veces (el 28\% del grupo) inferior.

\section{El reasentamiento de un hábitat a otro, praxis en Manizales}

Manizales, ciudad andina intermedia (380.000 Hab.), presenta una topografía muy accidentada, con suelos de origen volcánico poco compactos en una zona de alta sismicidad caracterizada por un clima ecuatorial bimodal de montaña (entre 2.500 y $3.000 \mathrm{~mm}$ de lluvia al año, de tipo torrencial con un fuerte poder erosivo). Esta situación permite explicar en parte la frecuente ocurrencia de movimientos en masa de gran poder destructivo.

Ante este contexto, el municipio trata de plantear soluciones de mitigación de la vulnerabilidad a través de procesos de reasentamiento que consisten en la adquisición como propietario, por parte de la comunidad vulnerable, de un lugar de vida nuevo o "usado" en un sitio supuestamente seguro desde el campo físico-natural. El principal objetivo de este tipo de medida es efectivamente proteger la vida y los bienes de la población. Los proyectos se plantean, como para muchos proyectos de Vivienda de Interés "Social..." (VIS), desde la relación costo/ beneficio y además, con un presupuesto muy limitado, puesto que para gran parte de la población soil in a highly seismic area characterized by mountain tropical climate $(2,500$ to $3,000 \mathrm{~mm}$ of yearly precipitation, characterized by its torrentiality and erosivity). This information is given to illustrate the frequent occurrence of highly destructive land movements.

In this context, the city council is finding solutions to reduce vulnerability through resettlement processes; these initiatives consist in acquiring a new or "pre-owned" house in a supposedly safe -from a physical-natural perspective- area. The main goal of these measures is to protect the life and goods of people. These plans are drawn up, as many of "Social" Interest Housing projects, considering the cost-benefit relation; they have a limited budget, as for most of the affected people, the main funding source are the housing subsidy given by the State (22 minimum wages, 5,200 USD) and the municipal subsidy (3,400 USD), covering $60-70 \%$ of the property value.

From a logistic-administrative perspective, the Popular Housing Fund (PHF) is -at local level- the governmental body responsible for the administrative, financial, architectural and urban management of SIH resettlement programs. 
afectada, la base es el subsidio de vivienda otorgado por el Estado (equivalente actualmente a veintidós salarios mínimos vigentes -USD 5200 a junio de 2010- y el subsidio municipal -USD 3.400-), logrando cubrir entre un 60 y un $70 \%$ del valor del inmueble. La parte restante en general se financia a través del sistema bancario. Desde el punto de vista logístico-administrativo, la Caja de la Vivienda Popular (CVP) es el ente público a cargo a nivel municipal de la gestión administrativa, financiera, arquitectónica y urbanística de los programas de VIS que incluyen los proyectos de reasentamiento.

En Manizales, los proyectos de reasentamiento se han caracterizado principalmente por cinco modalidades: 1- la simple entrega de un lote donde las personas volvían a armar su rancho de origen y luego, con el tiempo, el municipio construyó unidades básicas que los pobladores fueron ampliando y mejorando (Foto 1), 2- la entrega por parte de las autoridades de un lote donde las familias iban a construir una unidad básica, gracias a un subsidio del gobierno nacional y a una capacitación técnica por parte de la CVP y el SENA sobre normas de construcción (Altos de San Cayetano, 1990-1993), 3- el desarrollo de un proyecto integral (social, económico, físico-natural y físico-espacial) con la entrega de viviendas de $55 \mathrm{~m}^{2}$ (Foto 2), 4- la entrega llave en mano de unidades básicas de menos de $30 \mathrm{~m}^{2}$ con subsidios (Fotos 3, 4, 5 y 6) y 5 - la modalidad Vivienda Usada que consiste en comprar con los subsidios, una unidad usada escogida por la
In Manizales, resettlement initiatives have offered five solutions: 1- people were provided with land so that they could rebuild their original habitat; later on, the city council built social housing that was improved and expanded by dwellers. See picture 1; 2- people were provided with land so that they, through governmental subsidy and training on building standards conducted by the PHF and the National Service for Learning, could build basic housing (Altos de San Cayetano, 19901993); 3- the development of a comprehensive (social, economic, physical-natural and physical spatial) project, providing people with $55 \mathrm{~m}^{2}$ housing. See picture 2; 4- people were provided with subsidized $30 \mathrm{~m}^{2}$ housing. See pictures 3, 4, 5 and 6; 5-Pre-Owned Housing option, consisting in buying subsidized housing that meet building standards.

\section{The Original Habitat}

People who took part in resettlement processes in Manizales belong to the lowest socio-economic groups. They lived in steep, flood-prone areas near the downtown of the city. See pictures 7 and 8. These low income, irregular and mostly large families (more than six members) lived 


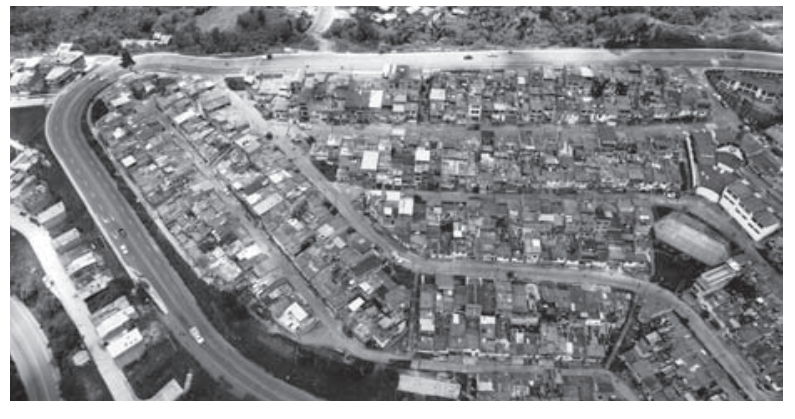

FOTO 1. Barrio El Paraíso, 1987. Fuente: Zepelín Ltda. PICTURE 1. El Paraíso neighborhood, 1987. Source: Zepelín Ltda

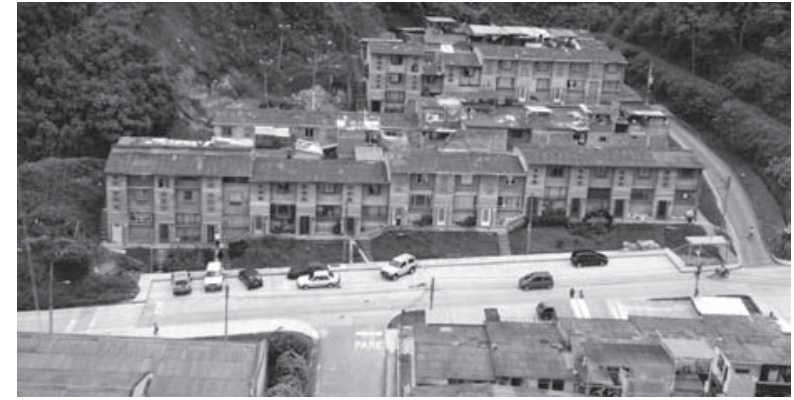

FOTO 2. Barrio Yarumales, 1995. Fuente: Zepelín Ltda. PICTURE 2. Yarumales neighborhood, 1995. Source: Zepelín Ltda

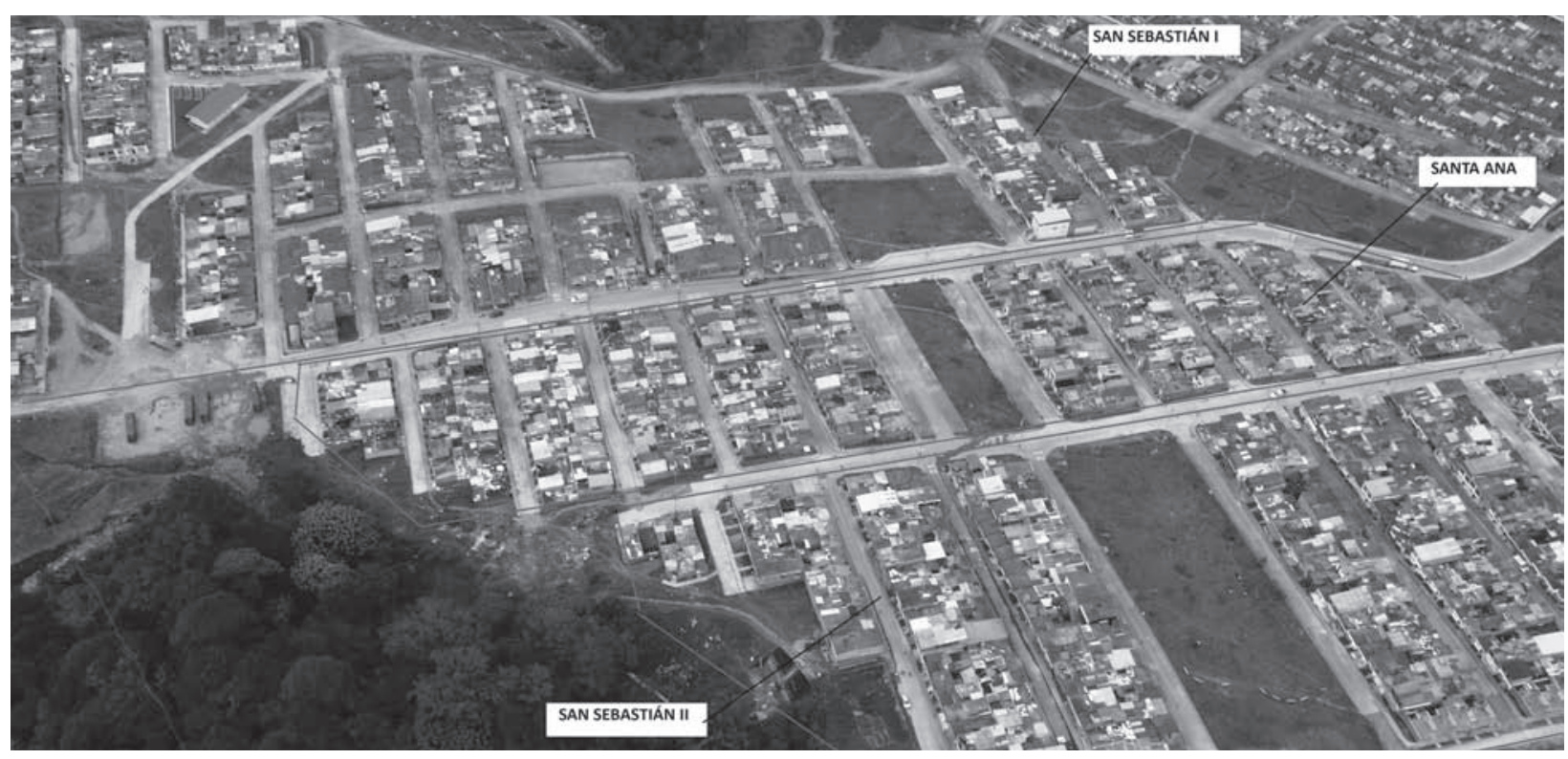

FOTO 3. Urbanizaciones San Sebastián a partir de 2002-2003 y Santa Ana, 2005. Fuente: Zepelín Ltda PICTURE 3. San Sebastián neighborhood 2002-2003 and Santa Ana neighborhood, 2005. Source: Zepelín Ltda 


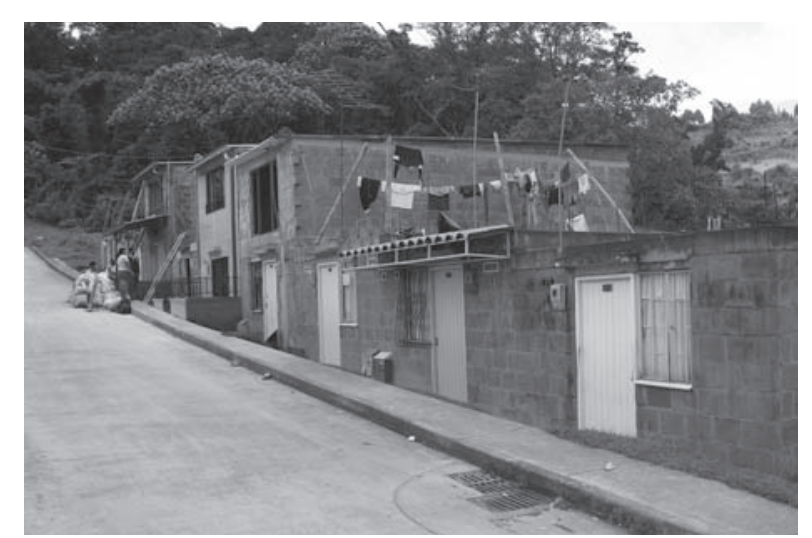

FOTO 4. Calle en Santa Ana, 2005. Fuente: Anne-Catherine Chardon. PICTURE 4. Street at Santa Ana neighborhood. Source: AnneCatherine Chardon

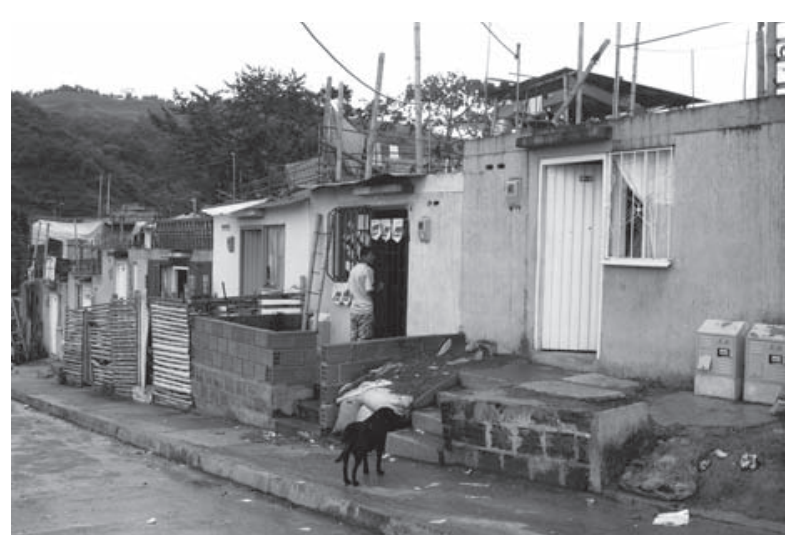

FOTO 5. Urbanización Portón del Guamo, 2005-2006. Fuente: Anne-Catherine Chardon.

PICTURE 5. Portón del Guamo neighborhood 2005-2006. Source: Anne-Catherine Chardon

46 revista invi № 70 / Noviembre 2010 / Volumen № 25: 17-75

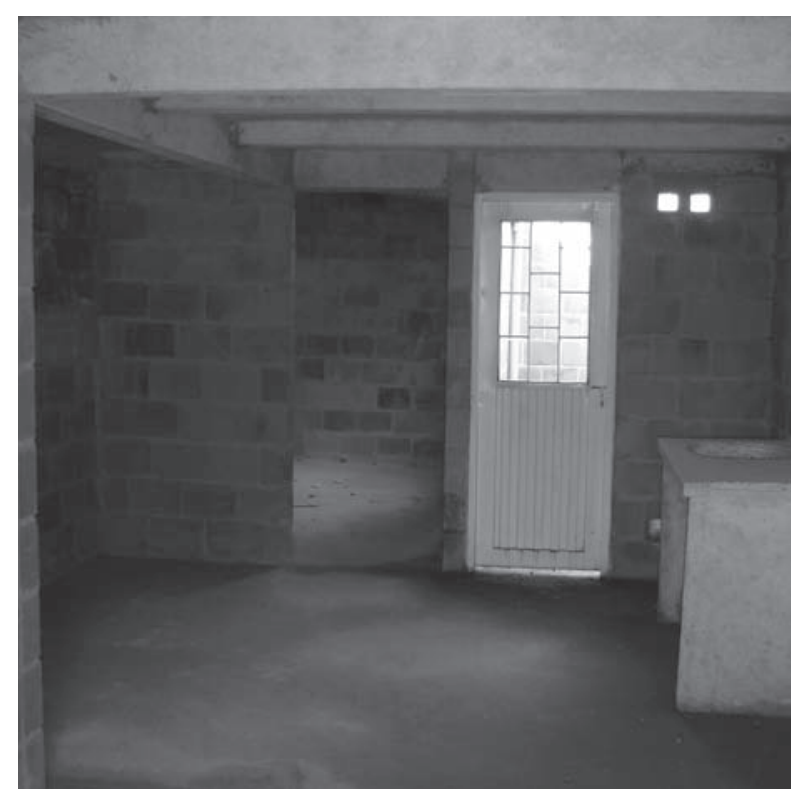

FOTO 6. Unidad básica 29m², 2008. Fuente: Anne-Catherine Chardon.

PICTURE 6. $29 \mathrm{~m}^{2}$ basic housing, 2008. Source: Anne-Catherine Chardon 
familia y que cumpla las normas de construcción vigentes.

\section{El hábitat de origen}

La población que en Manizales ha hecho parte de procesos de reasentamiento, pertenece a asentamientos de estratos 1 y 2 ubicados en zona de ladera muy pronunciada cerca del centro de la ciudad o a veces, en sectores inundables (Fotos 7 y 8). Las familias, en general numerosas (más de seis miembros) con ingresos económicos bajos y además irregulares, vivían en construcciones elaboradas de manera precaria, tanto en cuanto a materiales como a sistema constructivo o condiciones mínimas de higiene y salubridad. De igual manera, el área construida, con frecuencia, no respondía a las necesidades óptimas de desarrollo según el número de personas que tenían que cohabitar bajo el mismo techo, sin embargo, la superficie habitable era mucho más amplia que lo que luego se les entregó como supuesta solución a su vulnerabilidad (Fotos 9 y 10). El entorno físico-espacial se caracterizaba por una morfología orgánica donde, a pesar del hacinamiento evidente, se notaba la presencia de zonas verdes, en general cultivadas (cultivos de pan coger) y circulaciones de predominio peatonal (caminos y escalinatas, Fotos 11 y 12). En cuanto al nivel de equipamiento de carácter social, se tenía acceso a la totalidad de los servicios mínimos (Gráfico 1). in poor houses, as far as material, building system and hygiene and health conditions are concerned. In addition, these constructions, according to the number of people who lived in the same household, did not meet the ideal requirements of development; however, the inhabitable area of the houses these families were given was less spacious than the original one. See pictures 9 and 10. The physical-spatial environment was characterized by its organic morphology, which, although the evident overcrowding conditions, showed cultivated green areas (subsistence crops) and pedestrian structures (roads and steps). See pictures 11 and 12. Regarding social amenities, there was access to all basic services. See graphic 1.

With respect to the original habitat, the area was occupied either by the official owners or by tenants; the illegal access to basic services was a common practice.

As for employment, job activities were limited to small craft workshops and groceries; however, the proximity to the downtown meant that dwellers could take part in informal trade without allocating resources for transport. 


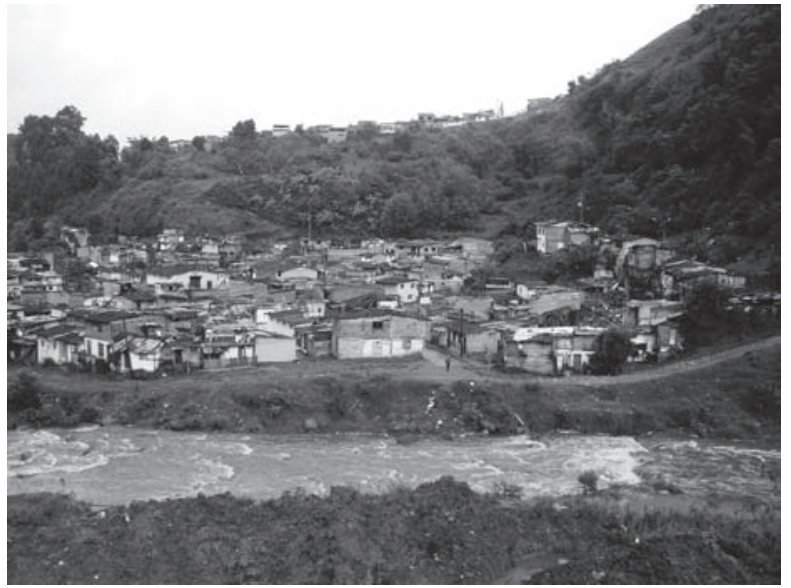

FOTO 7. Barrio La Playita reasentado en su totalidad (más de 600 familias) entre 2007 y 2008. Fuente: Anne-Catherine Chardon. PICTURE 7. La Playita neighborhood fully resettled (more than 600 families) from 2007 to 2008. Source: Anne-Catherine Chardon

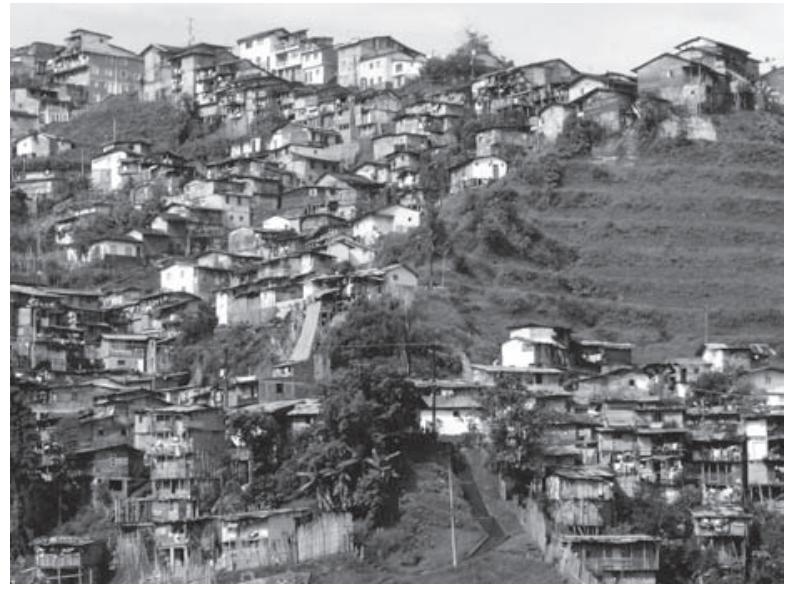

48 revista invi № 70 / Noviembre 2010 / Volumen № 25: 17-75

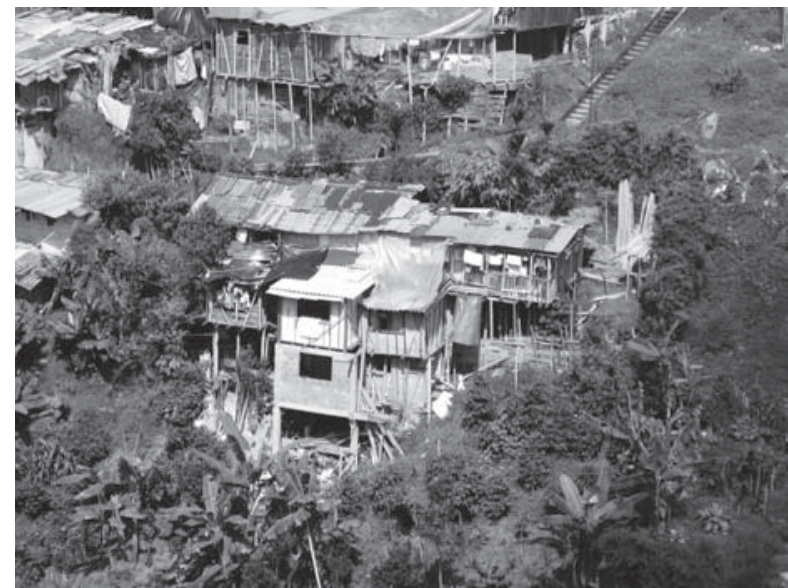

FOTO 9. Sector Bajo Andes, una vivienda tipo "Lego" con mezcla de sistemas constructivos y materiales. Fuente: Anne-Catherine Chardon.

PICTURE 9. "Lego-brick" housing mixing building and material systems, Bajo Andes area. Source: Anne-Catherine Chardon

FOTO 8. Barrio Galán, ladera norte. Fuente: Anne-Catherine Chardon.

PICTURE 8. Galán neighborhood, northern hillside. Source: AnneCatherine Chardon 


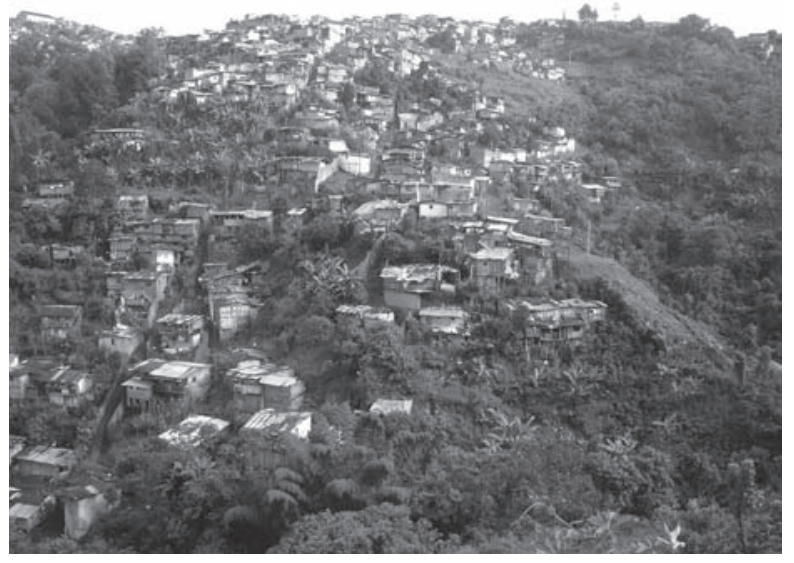

FOTO 10. Sector Bajo Andes, el tamaño de la vivienda es adaptado a los usos y necesidades de sus pobladores. Fuente: Anne-Catherine Chardon.

PICTURE 10. Bajo Andes area, the size of the house is adapted to the needs and uses of dwellers. Source: Anne-Catherine Chardon.

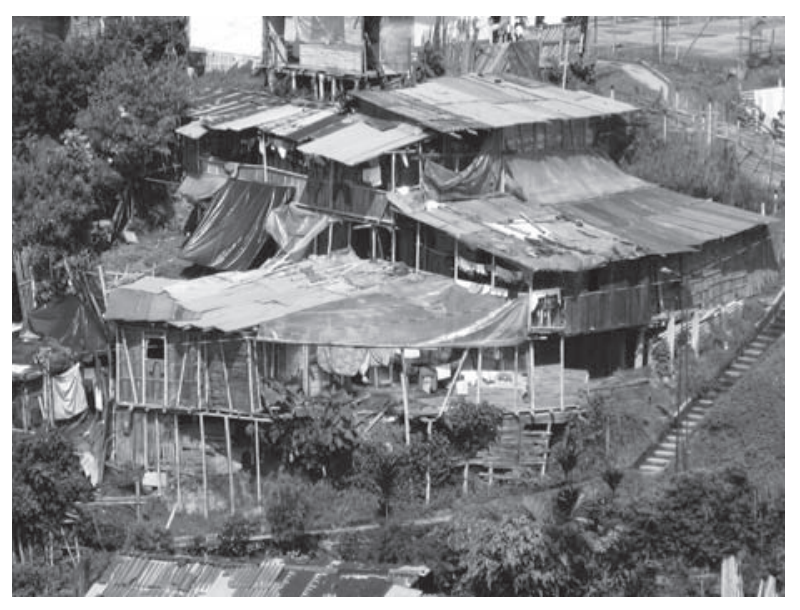

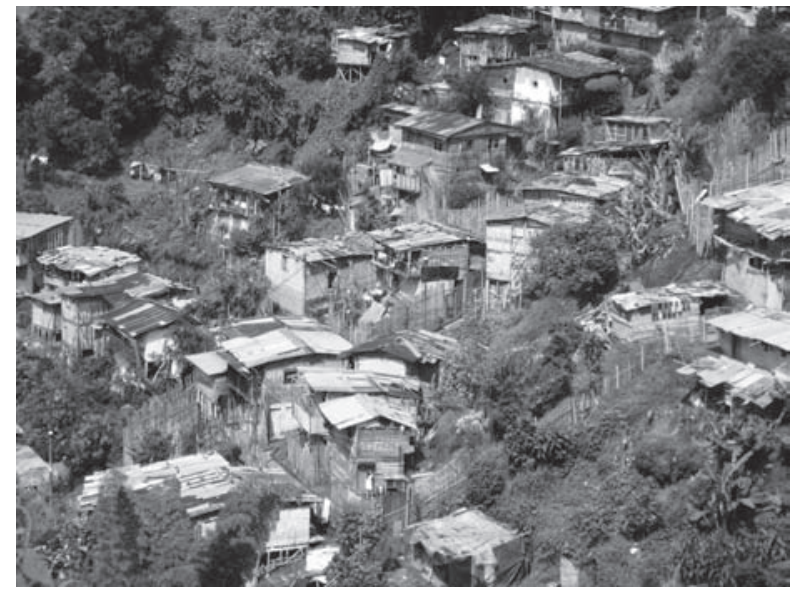

FOTO 12. Sector Bajo Andes. Los cultivos de pan coger rodean las viviendas. Fuente: Anne-Catherine Chardon.

PICTURE 12. Bajo Andes area, subsistence crops surrounding the houses. Source: Anne-Catherine Chardon.

FOTO 11. Barrios El Nevado y Los Andes, ladera sur, con circulación exclusivamente peatonal. Fuente: Anne-Catherine Chardon.

PICTURE 11. Ways for exclusive use of Bajo pedestrians, El Nevado and Los Andes neighborhoods, southern hillside. Source: Anne-Catherine Chardon. 
Desde el punto de vista de la finca raíz, los moradores ocupaban el sitio como propietarios oficiales o como propietarios de hecho o pagando un arriendo moderado. En cuanto a acceso a los servicios públicos, la ilegalidad de la conexión era común.

Con relación al campo laboral, las fuentes de empleo en el barrio se limitaban a la presencia de pequeños talleres artesanales o mini locales comerciales (tiendas), pero la cercanía al centro de la ciudad permitía, sin gastos de transporte, participar de la economía del "rebusque" o informal.

Desde el punto de vista relacional, el lugar de origen ha representado para las familias, el nicho "privilegiado", puesto que en general vivía en el mismo barrio o en la misma casa, el núcleo familiar ampliado, es decir, varias generaciones u hogares de una misma familia. De igual manera, también se podía contar con las relaciones de vecindario, la solidaridad del entorno humano.

La relación con el hábitat de origen oscilaba entre amores y odios, según la encuesta realizada. Al 61\% de las personas encuestadas, les parecía bueno el barrio de origen, resaltando que los aspectos agradables eran los vecinos, la cercanía al centro de la ciudad o equipamientos particulares y la tranquilidad que ahí se vivía. De hecho, el 82\% comenta que el ambiente con los vecinos era bueno, y adicionalmente el $60 \%$ afirma que en el barrio vivían familiares. Se observa entonces que este aspecto de las relaciones humanas y de sentirse bien en el en-
Since families lived in the same neighborhood or house, respondents, when asked about recreational activities, regarded their original habitat as their "privileged" space. Additionally, people could count on neighborhood relationships, that is to say, the solidarity of the human environment.

According to the survey, respondents had mixed reactions about their relationship with the original habitat. Sixty one percent of them had positive opinions about their original zone of residence; they pointed out aspects such as the neighbors, private amenities, the proximity to the downtown of the city and the peacefulness of the area. In fact, the $82 \%$ of those polled said there were good relationships among neighbors; additionally, the $60 \%$ of respondents stated they had relatives living in the same neighborhood. Then, human relationships and the sense of feeling comfortable in the life environment are essential, they become constituent parts of habitat and represent a key element of welfare, ensuring a certain degree of emotional stability. Regarding the location of residence in relation to urban centrality, amenities and services, that is to say, to urban dynamics, its value may or may not consider proximity. In the case of Manizales, the downtown of the 


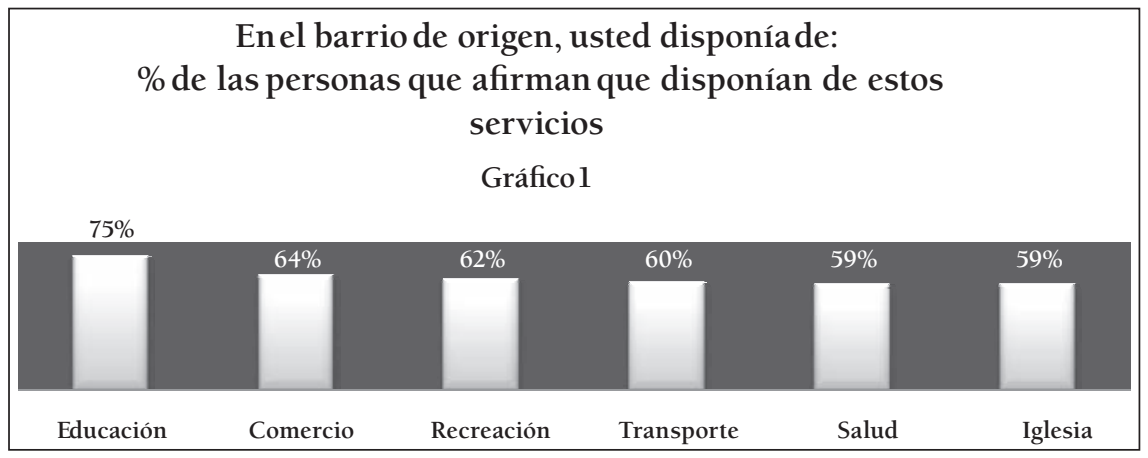

GRÁFICO 1. Fuente: Anne-Catherine Chardon. GRAPHIC 1. Source: Anne-Catherine Chardon.

torno de vida es esencial, hace parte del hábitat y representa entonces uno de los pilares fundamentales de la sensación de bienestar y seguramente permite asegurar cierta estabilidad emocional. En cuanto a la ubicación del lugar de vida con relación a la centralidad urbana y equipamientos o también servicios, es decir ligada a las dinámicas urbanas, su valoración tiene en cuenta la existencia o no de la proximidad. En el caso particular de Manizales, el centro representa el corazón comercial, bancario y de la mayoría de las actividades terciarias y por consiguiente, para las clases bajas o medias, la importancia de vivir cerca del centro pasa por el hecho de no tener que pagar transporte para desarrollar la mayoría de las actividades diarias (mercar, pagar servicios, adelantar trámites administrativos, etc.). city concentrates trade, banking and tertiary activities; therefore, as far as the closeness to the downtown area is concerned, what matters the most to low and middle classes is the fact of not allocating resources for transport to develop daily activities (doing the groceries, paying services, doing paperwork in advance, etc.)

In addition, the satisfaction level of respondents regarding the original neighborhood is due to the quality of amenities, which, according to graphic 1 was higher in relation to basic services and the house itself. See graphic 1. 
Adicionalmente, el grado de satisfacción significativo que la gente expresa en la encuesta con relación a su barrio de origen, se debe en gran parte al nivel de equipamiento que, como lo ilustra el Gráfico 1, era bastante elevado con relación a los servicios básicos necesarios a diario y a la calidad del principal objeto de interés: la casa.

Ahora bien, se expresaron también críticas hacia el barrio de origen como son principalmente la inseguridad, los niveles de drogadicción y estar en zona de riesgo. Las personas mencionan estas variables en mayor o menor porcentaje, pero todas las denuncian. Adicionalmente, en ciertas urbanizaciones se habla del difícil acceso por la topografía o de la mala calidad del transporte. El tema de la inseguridad y de la drogadicción que muy posiblemente le es asociado, representaban efectivamente un problema serio en los barrios de origen, puesto que apenas el 36\% dice que la seguridad en el barrio era buena. Estas afirmaciones permiten entender que el tema de la seguridad, en todas sus dimensiones, es de primera importancia y no se limita al peligro asociado a las amenazas naturales. Pasando de la escala del barrio a la de la casa, en promedio, al 61\% de las personas encuestadas les gustaba su casa porque era grande, cómoda y además bonita, acogedora. En cuanto a los lados negativos, la gente dice que la casa estaba situada en zona de riesgo y que los materiales de construcción eran de mala calidad. Efectivamente, a pesar
There was also criticism over the original neighborhood concerning insecurity, addiction to drugs and the fact of living in a vulnerable zone. Those polled mentioned these aspects in a greater or lesser degree, nevertheless, all of respondents reported those negative aspects. Additionally, inhabitants of certain zones mentioned the difficult access to those areas, either due to topographic conditions or to bad transport. Insecurity and addiction to drugs represented a serious problem in the original neighborhood, as the $36 \%$ of respondents had good comments about security. These statements suggest that insecurity, at all scales, is of utmost importance and is not only limited to natural threats.

At household level, the 61 percent of those that were surveyed liked their houses because they were spacious, comfortable, beautiful and cozy. As for the negative aspects, people said their houses were located in a vulnerable zone and the materials used for their construction were mediocre. In effect, despite missing certain aspects of their former houses, especially those related to spaciousness, dwellers know their lives were endangered and their houses had serious structural problems. This combination 
de anhelar ciertos aspectos de la casa de origen, sobre todo su tamaño, los pobladores eran conscientes que ahí su vida estaba en peligro y que la edificación presentaba grandes falencias constructivas, situación que los motivó a participar de un programa de reasentamiento.

Después del planteamiento del contexto de origen de las personas reasentadas, importa comentar tres proyectos de reasentamiento desarrollados en la ciudad con modalidades distintas en diferentes épocas, a fin de analizar sus beneficios y aspectos reprochables, desde una visión integral de hábitat.

\section{El hábitat de destino}

A continuación, se van a presentar dos proyectos de reasentamiento desarrollados en la ciudad y representativos de extremos cualitativos (El Paraíso y Yarumales) y una tercera ejecución correspondiente a un ejemplo del modelo llevado a cabo a lo largo de los últimos años (Santa Ana).

El primer programa de reasentamiento masivo realizado en Manizales llevó a la conformación del barrio El Paraíso, asentamiento que resultó en 1987 del traslado de 425 familias humildes que habían sido damnificadas por deslizamientos o que vivían en sectores amenazados por este fenómeno en cinco barrios de la ciudad. El ejercicio se limitó a la entrega gratuita de un lote seguro donde los hogares podían ubicar el rancho donde habían vivido hasta el mo- of events motivates them to take part in resettlement processes.

After discussing the aspects regarding the former habitat of resettled people, it is worth commenting three resettlement projects developed in different periods of time -using different procedures-, so that analyzing, from a comprehensive view of habitat, their benefits and mistakes.

\section{The Destination Habitat}

Two resettlement processes illustrating qualitative opposites (El Paraíso and Yarumales), as well a third initiative, based on a model that is currently in use (Santa Ana) are examined.

The first large scale resettlement program implemented in Manizales led to the creation, in 1987, of El Paraiso neighborhood; this settlement was the result of the relocation of 425 families affected by landslides; groups of people from five different neighborhoods threatened by landslips were also considered. This resettlement initiative consisted in providing people with land, so that they could rebuild their original habitat; as the former houses 
mento, desmontando y trasladándolo con facilidad, puesto que los asentamientos de origen solían ser de guadua (bambú) y materiales de recuperación. Desde el punto de vista físico-espacial, el proceso de evolución del barrio consistió, después de unos años, en la construcción por parte del municipio, de una unidad básica en obra negra (espacio múltiple, baño, cubierta y emplazamiento de una puerta de entrada y un vano, Fotos 13 y 14). Más adelante, cada familia a su ritmo y gusto amplió la unidad, en general con ladrillos o bloques de cemento. Actualmente, más de veinte años después del inicio del proceso, la urbanización está muy consolidada, ya no hay rastro de los orígenes, la transformación físico-espacial se ha ido realizando al ritmo y gusto particular de cada hogar, generando una gran heterogeneidad a nivel de número de plantas, fachada, materiales, textura, color, etc (Fotos 15 y 16). Desde el punto de vista del uso público, el sector cuenta con equipamientos básicos (escuela, colegio, puesto de salud, cancha de deporte, iglesia, comercio de proximidad), pero con muy pocas zonas verdes y el espacio público "de borde" es muy limitado, pues el barrio está rodeado por una vía principal (Foto 1) de la ciudad, situación que sí permite tener acceso a un buen servicio de transporte.

En el ámbito socio-económico, en ningún momento se tuvo en cuenta el contexto particular de las familias objeto del proceso, situación que también era generadora de vulnerabilidad. Por consiguiente, las variables como educación, empleo, salud o were built with bamboo and salvage material, they were easily dismantled and taken to the new area. Later on, the city council built social housing (consisting of a multiple space, bathroom, roof, main door and an opening). See pictures 13 and 14. From a physicalspatial perspective, these constructions were part of the evolution of the neighborhood. Afterwards, families expanded their houses by using bricks or cement blocks. Today, 20 years on the beginning of the resettlement process, the neighborhood is consolidated and there are no traces of its origin and the physicalspatial transformation of the area develops at the pace of each family, as a result, there is heterogeneity regarding the number of floors, facade patterns, materials, texture, colors, etc. See pictures 15 and 16. As for public use, the neighborhood is equipped with basic amenities (schools, health facilities, multipurpose court, church, local shops); however, there are few green areas and despite being surrounded by a main road that facilitates the access to transport, the public space that separates the neighborhood from other zones is limited by this highway.

Regarding socio-economic aspects, the particular context of relocated families, an 


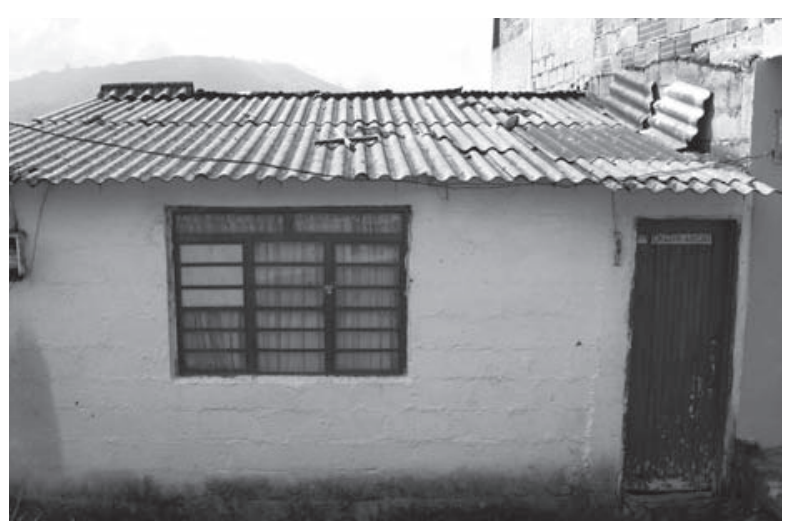

FOTO 13. Unidad básica entregada por el municipio después de unos años. Fuente: Anne-Catherine Chardon.

PICTURE 13. Social housing given by the city council after. Source: Anne-Catherine Chardon.

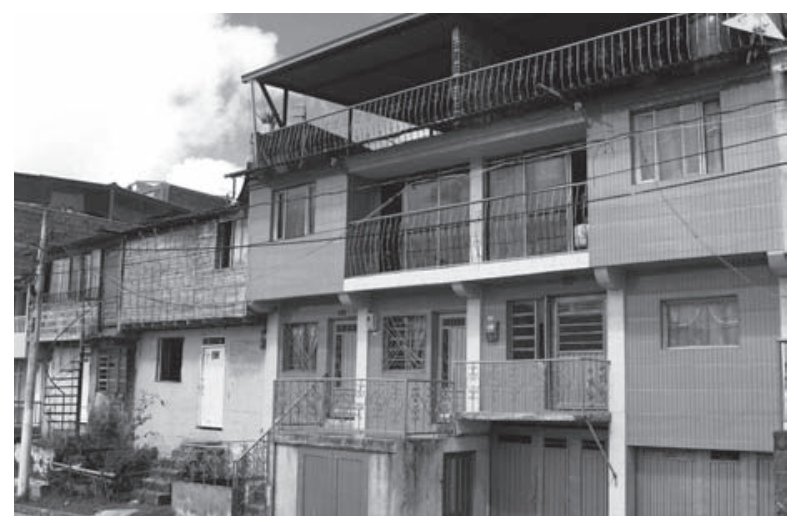

FOTO 15. Los procesos de consolidación individual son muy variados. Fuente: Anne-Catherine Chardon.

PICTURE 15. There is a series of individual consolidation processes. Source: Anne-Catherine Chardon.

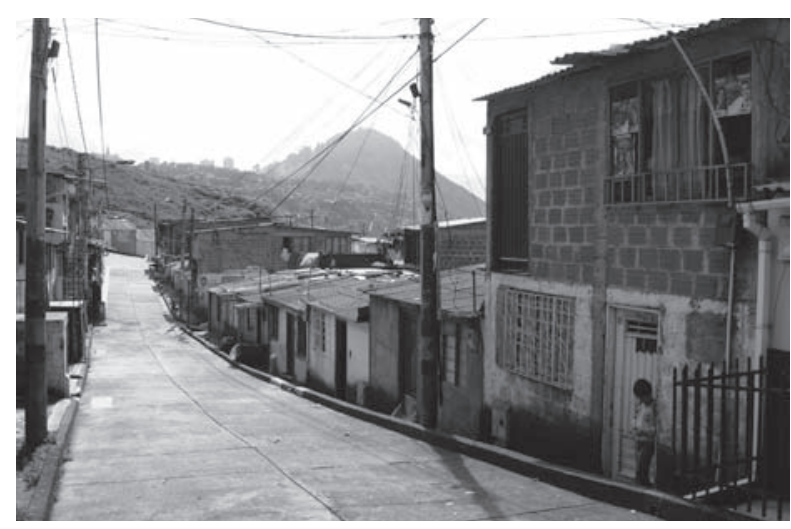

FOTO 14. Todavía, muchas familias viven en la unidad básica Fuente: Anne-Catherine Chardon.

PICTURE 14. A large number of families are still living in social housing. Source: Anne-Catherine Chardon.

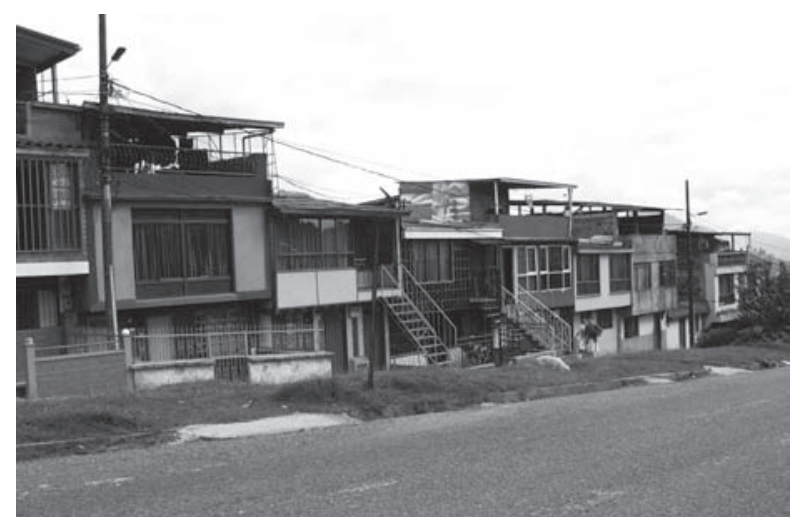

FOTO 16. Consolidación y heterogeneidad. Fuente: Anne-Catherine Chardon.

PICTURE 16. Consolidation and heterogeneity. Source: AnneCatherine Chardon.

revista invi № 70 / November 2010 / Volume № 25: 17-75

55 
convivencia no se consideraron. Esta visión muy técnica y casi exclusivamente desde la geología generó una serie de situaciones que demostraron el fracaso a corto y mediano plazo del proceso.

Es así como al poco tiempo de haberse trasladado, un número significativo de familias vendió el lote seguro adjudicado de manera gratuita y se devolvió a su barrio de origen, lo cual por supuesto anuló la iniciativa del municipio. Dicha práctica se pudo presentar porque las autoridades no ejercieron ningún control sobre el proceso, pues consideraron que con esta reubicación espacial, habían cumplido su misión.

De igual manera, por el desempleo, la falta de acompañamiento social hacia la comunidad, el contexto social del nuevo asentamiento El Paraíso mostró señas alarmantes de deterioro a través del tráfico de drogas, armas, inseguridad, prostitución, etc. Efectivamente, el trasteo no es solamente material, pues los usos, costumbres y otros modos de vida también se trasladan de un lugar a otro, para bien o para mal...

Paulatinamente, la comunidad del sector se fue consolidando por "autoconstrucción" y por la intervención de algunas ONGs y universidades locales, hasta llegar a su situación actual de cierta estabilidad donde los pobladores expresan un alto nivel de agrado hacia sus condiciones de vida, pero el proceso de mejoramiento de la calidad de vida fue lento. element that also created vulnerability, was not considered. Therefore, aspects such as education, health or communal life were not taken into account. This geological and technical approach generated a series of circumstances that meant the short and mid term failure of the process.

That is why an important number of families sold their new land and returned to their former habitat shortly after being relocated, as a result, the city council program was canceled. This action was motivated by the lack of governmental control over the process, as authorities thought that spatial resettlement was enough to solve the problems of vulnerable families. Likewise, due to unemployment and segregation, the social context of El Paraiso showed alarming signs of deterioration through drugs and arms trafficking, insecurity, prostitution, etc. Indeed, resettlement is not only material, as habits, customs and other ways of life are also relocated, be it good or bad...

Gradually, the community of El Paraíso began to grow by "self-destruction", as well as by the intervention of NPOs and local universities until reaching its current stable state, with dwellers expressing satisfaction about life conditions; 
En la siguiente década, la urbanización Yarumales (Foto 2), al contrario de la situación anterior, se pensó de manera holística y podría ser calificada de modelo a seguir. En 1993, la CVP y la organización El Minuto de Dios realizaron un programa de gestión global de reubicación, que duró dos años. Efectivamente, el proyecto consistió no solamente en reubicar a las 36 familias, sino también en trabajar temas socio-económico-culturales con la comunidad por reubicar, bajo la forma de talleres semanales y con participación obligatoria de todos los miembros de la familia; entre otras, se realizaron capacitaciones en el campo de la modistería, zapatería y panadería, a fin de que las familias pudieran generar los ingresos necesarios a su sostenimiento y al pago de las cuotas de la nueva casa. Además, El Minuto de Dios era consciente que era fundamental tratar de conformar una comunidad donde no existía, pues las familias que iban a ser reasentadas vivían inicialmente en barrios distintos, por consiguiente tenían que aprender a conocerse.

Era evidente que la vulnerabilidad que se pretendía mitigar por medio del proyecto no se limitaba a la expresión de factores físico-naturales o técnicos, sino que también se debía a un contexto social, cultural y económico poco favorable sobre el cual era necesario actuar tanto en el interior de las familias, como a nivel comunitario, es decir, con una visión de hábitat acertada. nevertheless, the life quality improvement process was slow.

In the following decade, the Yarumales settlement, contrary to El Paraíso, was planned in a holistic way and it should be considered as a pattern to follow. See picture 2. In 1993, the PHF and the God's Minute organization developed a comprehensive resettlement process that lasted two years. In effect, the initiative was not only about relocating 36 families, but working along the community on socio-economic-cultural aspects; dwellers had to attend compulsory weekly workshops on dressmaking, shoemaking and bakery so that all families could generate income to pay daily expenditures and house installments. In addition, God's Minute was aware of the importance of establishing a new community, since relocated families came from different neighborhoods and they had to know each other.

It was clear that this project addressed not only technical or physical-spatial aspects of vulnerability, but also social, cultural and economic factors at private and communal levels with a proper approach to habitat.

As for physical-natural and physical-spatial spheres, the initiative had a broad view that 
En cuanto a las dimensiones físico-natural y físicoespacial, el proyecto también expresó una mirada amplia y sobre todo sin los estereotipos habituales "proyecto pobre para pobres". El lote escogido para el desarrollo del programa estaba ubicado en un sector ya consolidado y tradicional de la ciudad que contaba con todos los servicios e infraestructuras mínimas. Desde el punto de vista urbanístico, las áreas libres se componían de antejardines, circulaciones peatonales, un pequeño parque infantil, una cancha de deporte y una zona de parqueo, actualmente todos en excelente estado, como prueba del sentido de pertenencia de la comunidad (Foto 17).

Finalmente, con relación al diseño urbano-arquitectónico del proyecto, éste fue realizado por un grupo de estudiantes y profesores de arquitectura, cuyo resultado permite observar una real búsqueda de diseño y unas áreas construidas de alrededor de $55 \mathrm{~m}^{2}$ distribuidos sobre dos plantas habitables en el momento de su entrega (Foto 18).

En 1995, las familias se pasaron al nuevo barrio Yarumales y, después de quince años de haber sido entregadas, apenas el 10\% de las construcciones ha sufrido una remodelación o ampliación, lo cual demuestra que los pobladores se han sentido a gusto con el proyecto inicial.

Hasta la fecha, en Manizales, esta experiencia ha sido única, pues como se verá a continuación, los últimos procesos de reasentamiento del presente siglo (San Sebastián, Samaria, Santa Ana, Portón escaped from the "poor project for poor people" stereotype. The land chosen to develop the program was located in a consolidated and traditional area of the city; it had all basic services and infrastructure. From a townplanning perspective, free areas were composed of front yards, pedestrian traffics, a little playground, a multipurpose court and a parking area; all of these elements are in excellent state, as a proof of the sense of belonging of the community. See picture 17.

In relation to the urban-architectural design of the project, it was developed by a group of architecture students and professors. The result suggests a real search for design and a $55 \mathrm{~m}^{2}$ built-up area distributed in two inhabitable floors. See picture 18.

In 1995, families moved to Yarumales neighborhood, and, 15 years after being handedover to their owners, only the 10\% of houses were remodelled or expanded, suggesting that dwellers feel comfortable with the initial project.

So far, the Yarumales program is the only of its kind in Manizales, as resettlement processes implemented during the last decade (San Sebastián, Samaria, Portón del Guamo y Mirador de Monteleón) have a narrow and wrong view of habitat. 


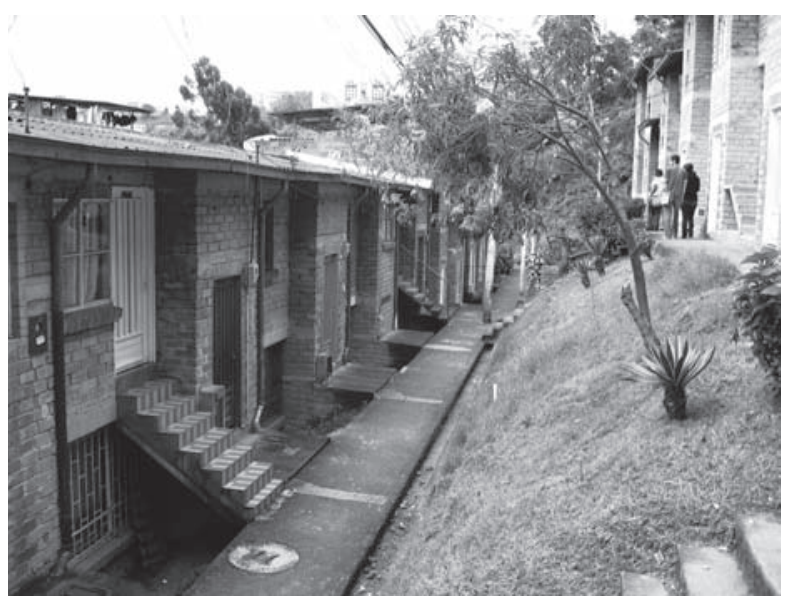

FOTO 17 . Un entorno urbanístico muy agradable. Fuente: AnneCatherine Chardon.

PICTURE 17. Welcoming urban environment. Source: Anne-Catherine Chardon.

del Guamo y Mirador de Monteleón) fueron planteados con una visión muy limitada y errónea desde el enfoque del hábitat.

La urbanización Santa Ana correspondió a la solución de vivienda que el municipio, por medio de la CVP, se comprometió a entregar a las familias damnificadas durante la noche del 18 de marzo de 2003, cuando en tres horas, se registraron 144 $\mathrm{mm}$ de lluvias, las cuales ocasionaron innumerables deslizamientos de magnitud considerable en varios sectores inestables de la ciudad.

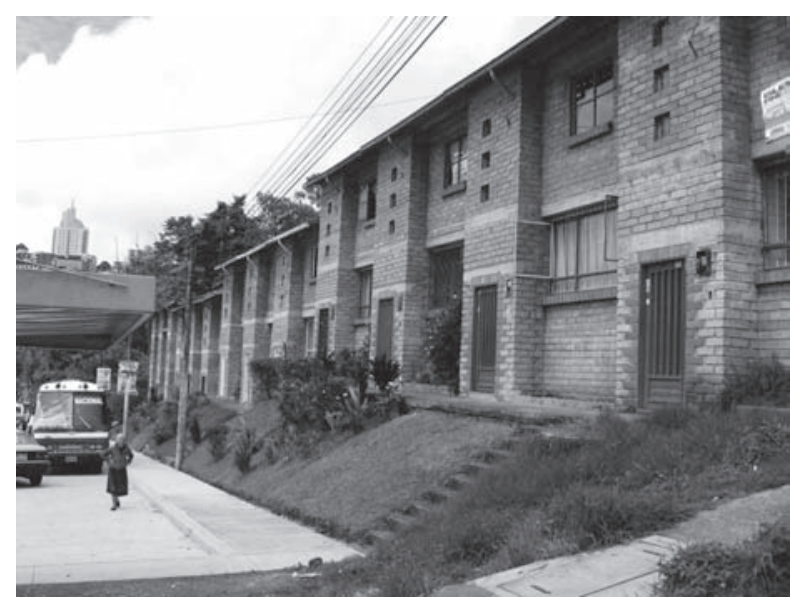

FOTO 18. Un proyecto habitablemente digno. Fuente: Anne-Catherine Chardon.

PICTURE 18. Decent inhabitable project. Source: Anne-Catherine Chardon.

The Santa Ana neighborhood was the solution offered by authorities, through the PHF, to those families affected on March the $18^{\text {th }}, 2003$, when $144 \mathrm{~mm}$ of precipitation were measured in three hours, wich produced many large landslides in several unstable areas of the city.

The area consists of 11 blocks, with each area containing $39229 \mathrm{~m}^{2}$ houses (not housing) built on a $35 \mathrm{~m}^{2}$ plot; affected families inhabited this neighborhood in October, 2005. 


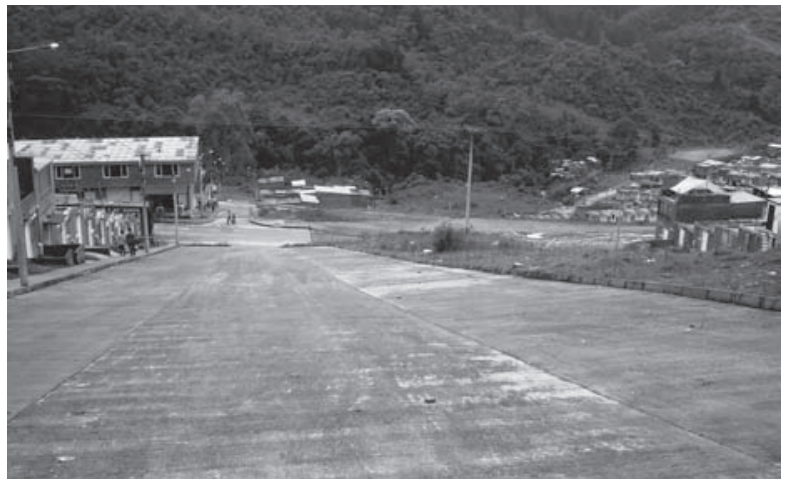

FOTO 19. Una urbanización orientada hacia la fuerte pendiente, afectando la calidad de vida. Fuente: Anne-Catherine Chardon

PICTURE 19. Neighborhood oriented along the gradient, affecting life quality. Source: Anne-Catherine Chardon.

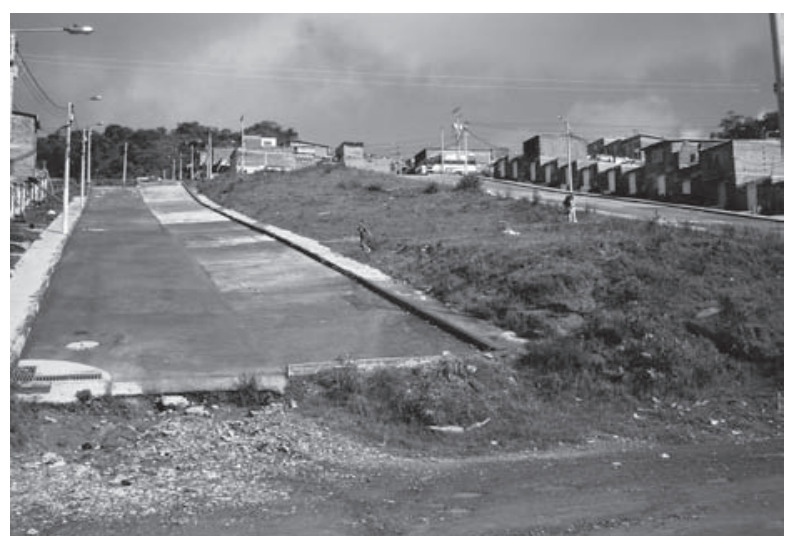

FOTO 21. Zonas de cesión sin adecuación. Fuente: Anne-Catherine Chardon.

PICTURE 21. Unfinished cession areas. Source: Anne-Catherine Chardon.

60 revista invi № 70 / Noviembre 2010 / Volumen № 25: 17-75

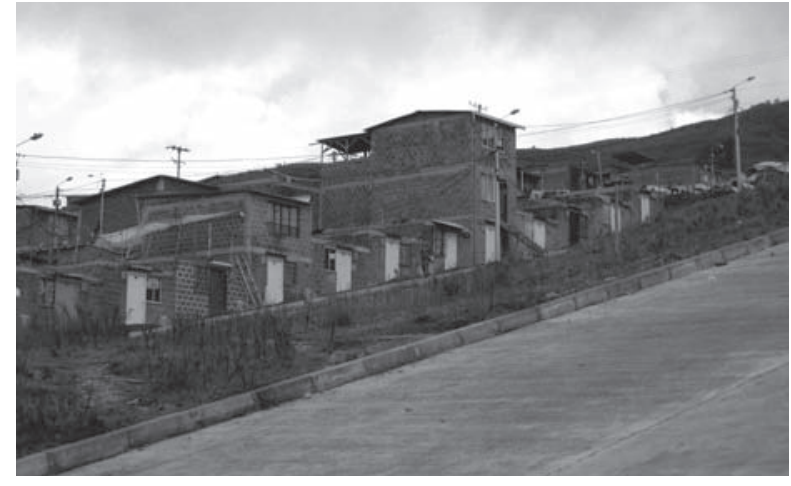

FOTO 20. La orientación de las viviendas impide aprovechar la visual Fuente: Anne-Catherine Chardon.

PICTURE 20. The orientation of houses prevents from seeing the environment. Source: Anne-Catherine Chardon.

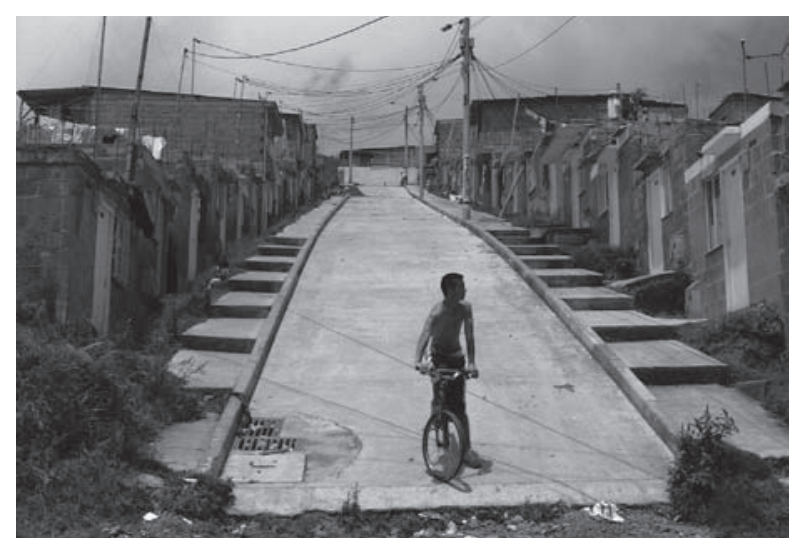

FOTO 22. Falta de conexión urbanística con el entorno. Fuente: Anne-Catherine Chardon.

PICTURE 22. Lack of urban connection with the environment. Source: Anne-Catherine Chardon.

ARTICLE: Resettling a vulnerable habitat. Theory against practice /Anne-Catherine Chardon 
El sector consta de 11 manzanas que reagrupan 392 casas (y no viviendas) de $29 \mathrm{~m}^{2}$ cada una (Foto 6), sobre un lote de $35 \mathrm{~m}^{2}$, adonde las familias damnificadas se pasaron a vivir en octubre de 2005.

Inicialmente, la urbanización estaba diseñada respetando las curvas de nivel, situación recomendable en terrenos de ladera, pero para permitir una circulación vehicular y con fines de rentabilidad, el proyecto está orientado en el sentido de la pendiente con vías y áreas de cesión muy inclinadas (Foto 19), edificaciones escalonadas (Foto 20) y un difícil uso de los espacios públicos que, además, carecen de equipamiento (Foto 21). Adicionalmente, la constructora se limitó a organizar el estricto perímetro interno de la urbanización, y por consiguiente, las conexiones con el entorno fueron inexistentes durante varios años (Foto 22).

Siempre desde el punto de vista urbanístico, el acceso a las casas es poco práctico y de uso exclusivamente peatonal por medio de escalas estrechas (Foto 23) y en el campo arquitectónico, la urbanización presenta unas características poco adecuadas cuando de hábitat se trata. Es así como a nivel arquitectónico, la solución supuestamente "habitacional" (Foto 6) se compone de un espacio social $\left(18,8 \mathrm{~m}^{2}\right.$, incluyendo un corredor), una habitación $\left(7,9 \mathrm{~m}^{2}\right)$, un patio $\left(5,2 \mathrm{~m}^{2}\right)$ y un baño $\left(3,25 \mathrm{~m}^{2}\right)$, de los cuales tiene que "disfrutar" un grupo familiar, siempre numeroso. Esta situación genera por supuesto un hacinamiento crítico que no permite se-
At first, this zone was intended to respect contour lines, which is the recommended procedure for hillside land; however, in order to make traffic possible, and for profit-making reasons, the project is oriented along the gradient, presenting sloped ways and cession areas, stepped constructions and public spaces that, as well as lacking amenities, are difficult to use. See pictures 19, 20, and 21. Additionally, the contracting firm developed only the inner perimeter of the neighborhood; as a consequence, there were no connections between Santa Ana and its proximities for several years. See picture 22.

From a town planning perspective, narrow stairs make the access to houses unpractical and for exclusive use of pedestrians. See picture 23. From an architectural point of view, the neighborhood presents characteristics that do not meet habitat standards. As a result, the "housing" solution consists of a social space $\left(18,8 \mathrm{~m}^{2}\right.$, including corridor), a bedroom $\left(7,9 \mathrm{~m}^{2}\right)$, a courtyard $\left(5,2 \mathrm{~m}^{2}\right)$ and a bathroom $\left(3,25 \mathrm{~m}^{2}\right)$, which are intended for the "benefit" of generally large families. See picture 6 . This situation creates critical overcrowding conditions, being impossible to separate communal, family and private uses. As these 


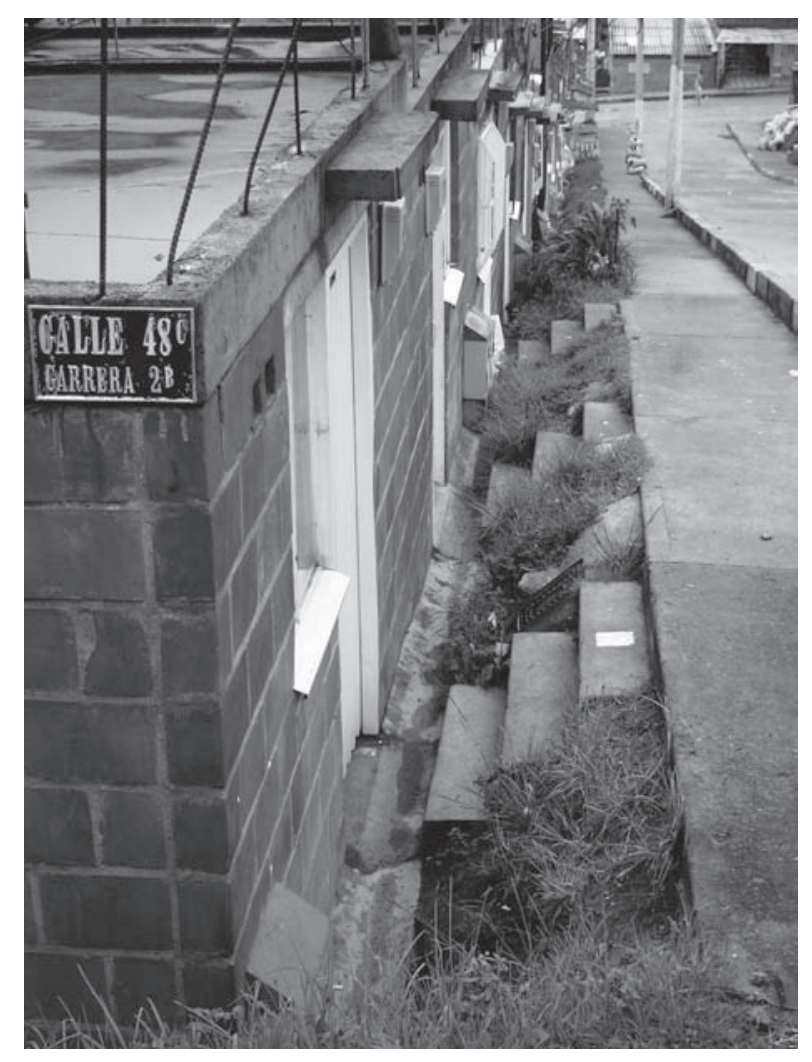

FOTO 23. Acceso exclusivamente peatonal y complicado. Fuente: Anne-Catherine Chardon.

PICTURE 23. Difficult and pedestrian- oriented access. Source: Anne-Catherine Chardon.

62 revista invi № 70 / Noviembre 2010 / Volumen № 25: 17-75

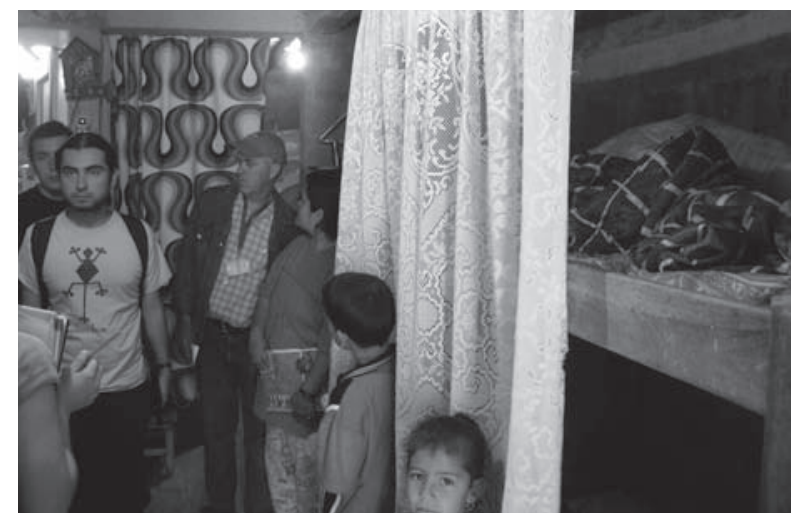

FOTO 24. La estrechez obliga a la subdivisión del espacio inicialmente social. Fuente: Anne-Catherine Chardon.

PICTURE 24. Due to the narrowness of the property, social spaces are divided. Source: Anne-Catherine Chardon.

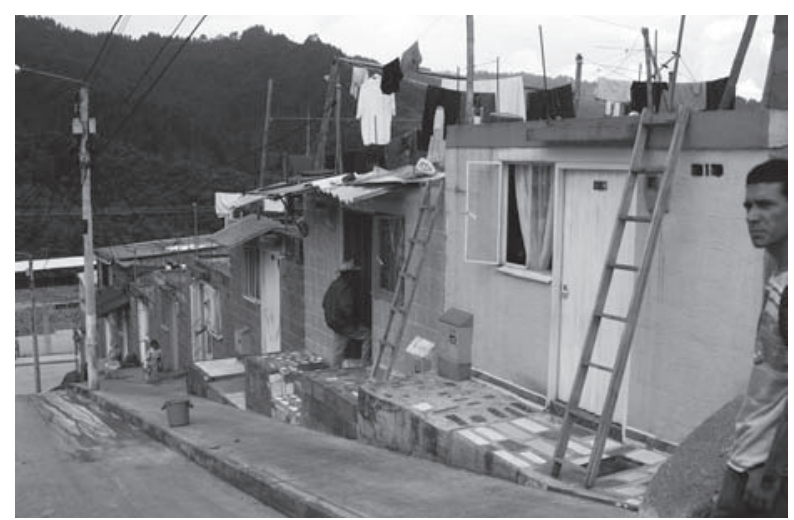

FOTO 25. A cada fachada, su escalera. Fuente: Anne-Catherine Chardon.

PICTURE 25. Every facade has its ladder. Source: Anne-Catherine Chardon.

ARTICLE: Resettling a vulnerable habitat. Theory against practice /Anne-Catherine Chardon 


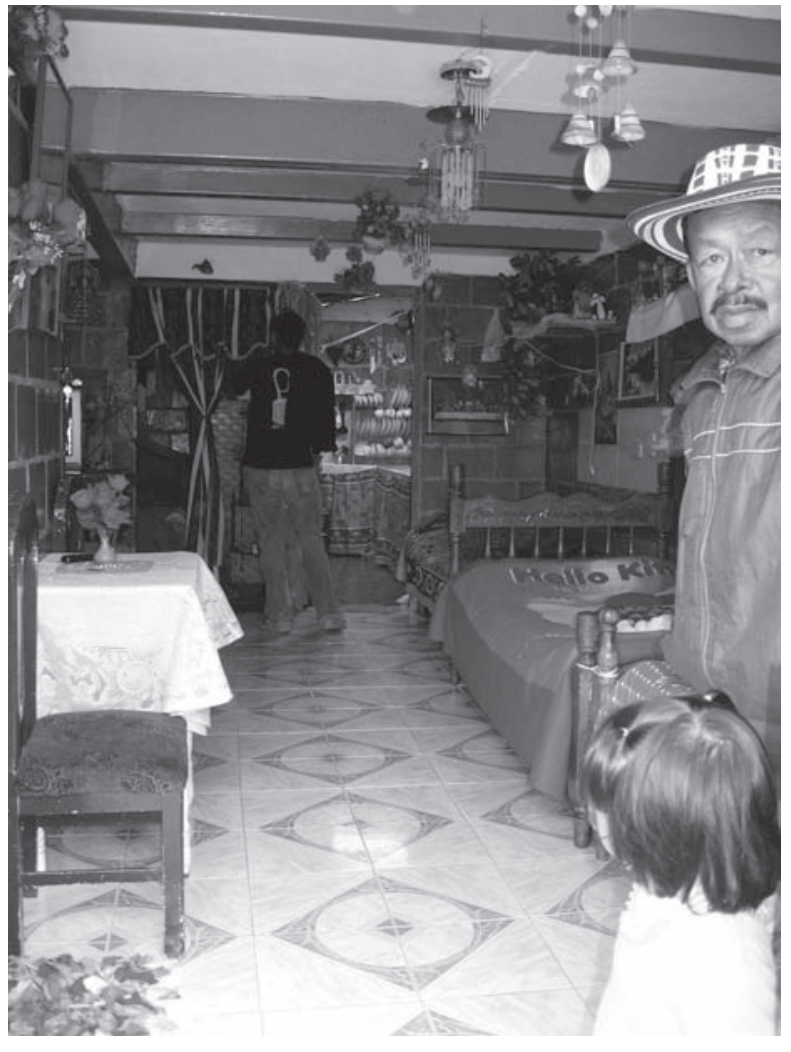

FOTO 26. La alcoba en la sala. Fuente: Anne-Catherine Chardon. PICTURE 26. The bedroom is located in the living room. Source: Anne-Catherine Chardon.

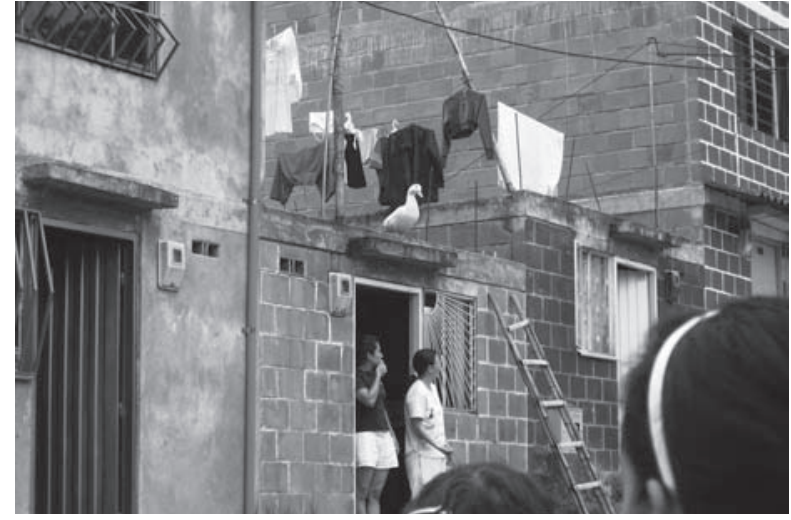

FOTO 27. La cubierta multi-uso permite duplicar el espacio habitable. Fuente: Anne-Catherine Chardon.

PICTURE 27. The multipurpose rooftop doubles the inhabitable space. Source: Anne-Catherine Chardon.

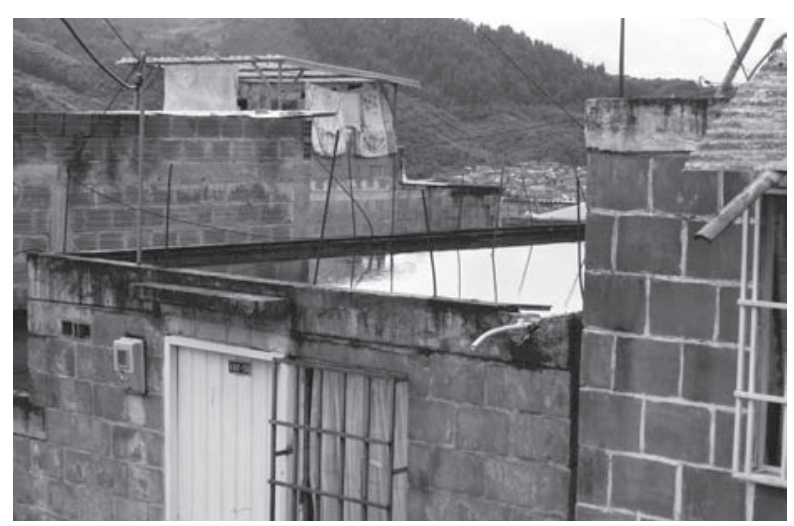

FOTO 28. Problema de humedad en la cubierta. Fuente: AnneCatherine Chardon.

PICTURE 28. Rooftop with humidity problems. Source: AnneCatherine Chardon. 
parar los usos social, privado e íntimo, pues estas tres categorías se tienen que desarrollar compartiendo espacios, los cuales se dividen por medio de cortinas o divisiones virtuales de uso (Foto 24).

De esta manera, el espacio social o de servicios se vuelve privado, transformándose en alcoba (Foto 26), y la estrechez también obliga a la ocupación de la cubierta que pasa a ser terraza donde juegan los niños, se toma el sol, se seca la ropa o se mantienen animales domésticos (Fotos 25 y 27). De hecho, la urbanización refleja la etapa de transición multidimensional en la cual se encuentra la comunidad reasentada. La distinción entre modos de vida urbano y rural no es clara, la primera planta parece urbana, mientras los usos de la terrazacubierta son netamente rurales con la presencia de criaderos de animales cercados como en una finca.

La carencia espacial se manifiesta, como en muchas situaciones similares, y obliga a la ocupación de los espacios públicos, convirtiéndolos en espacios privados; es el caso de los antejardines.

En este tipo de asentamiento, es muy común observar que el lugar de vida representa además una fuente de ingresos que permite, entre otras, poder responder por la responsabilidad financiera adquirida para la compra de la casa, ya que el proyecto no contempló la sostenibilidad económica de las familias. Es así como, en los mismos $29 \mathrm{~m}^{2}$, se puede desarrollar una pequeña actividad comercial como una tienda, un estanquillo o una peluquería. three categories are developed in the same spaces, dwellers use curtains to divide them. See picture 24.

In this way, social or service spaces turn into a private one, becoming a bedroom. See picture 26. Additionally, the narrowness of the construction turns the rooftop into a playground as well as a place for leisure, drying clothes and breeding domestic animals. See pictures 25 and 27. Indeed, this neighborhood represents the multiscale transition phase of the resettled community. There is no distinction between urban and rural ways of life, as the ground floor has urban characteristics and the rooftopterrace is a rural space for breeding purposes. As in similar situations, this lack of space leads to the appropriation of public areas such as front yards.

In this kind of settlement, the place of residence is a source of income that enables dwellers to pay for the house they have, as the project did not consider the economic sustainability of families. This is how small businesses such as stores, groceries and hairdressing salons are started up in these $29 \mathrm{~m}^{2}$ spaces. Naturally, limited habitat conditions are not exclusive to the built-up area, as there are also problems regarding illumination (one opening), acoustic 
Por supuesto, las pocas condiciones de habitabilidad no se limitan al área construida, sino que también se aplican a las condiciones lumínicas (un solo vano), acústicas (se comparte un muro con la casa vecina), de ventilación y humedad (la cubierta-terraza genera filtración de agua, Foto 28).

Por no haber sido tomados en cuenta en el momento del diseño y por la poca integración del concepto de hábitat en la edificación de la urbanización, los habitantes o más bien, las personas en proceso de construcción de su "habitan(t)-bilidad", han priorizado las transformaciones de su entorno, necesarias al mejoramiento de su calidad de vida y han optado por ampliar su casa, pintarla o sacarle provecho económico, demostrando que el anhelo es pasar de la casa a la vivienda.

Es así como, al poco tiempo, han ido apareciendo (sin mayor respeto de las normas) la segunda y la tercera planta, los ventanales, los balcones o los colores personalizados, procesos que, con frecuencia, se acompañan de la desaparición del patio.

Con el fin de evidenciar las diferencias entre estos tres modelos de reasentamiento presentados, se resume la información más relevante en la tabla 1.

La comparación de estos tres proyectos permitió entender que las políticas en materia de reasentamiento son coyunturales y no responden a una visión integral y madura de la situación, que podría dejar esperar que su fin es participar del desarrollo sostenible de las poblaciones reasentadas. Pocos progra- (a wall is shared with the neighboring house), ventilation and humidity (the rooftop-terrace causes water leakage). See picture 28.

Since dwellers were not considered in the design process of the neighborhood, and due to the fact that the concept of habitat was not fully applied in the construction of the area, inhabitants gave priority to the transformation of their environment, which is needed for the improvement of life quality, by expanding and painting their houses, as well as by making profit from it; it is demonstrated, then, that switching from house to housing is the wish of dwellers.

This is how inhabitants (without respecting standards) painted and added a second and third floors, large windows and balconies to their houses; all these processes implied the elimination of the courtyard.

The following table shows the differences among the three mentioned resettlement processes. See table 1.

By comparing these projects, it is possible to understand that resettlement policies depend on circumstances and do not consider the sustainable development of resettled communities. Most of programs concentrate 


\section{TABLA 1: CARACTERÍSTICAS MULTIDIMENSIONALES DEL REASENTAMIENTO}

\begin{tabular}{|c|c|c|c|c|c|c|c|c|c|}
\hline & $\begin{array}{l}\text { Ubica- } \\
\text { ción del } \\
\text { nuevo } \\
\text { sector }\end{array}$ & $\begin{array}{l}N^{0} \text { de } \\
\text { familias } \\
\text { reasen- } \\
\text { tadas }\end{array}$ & $\begin{array}{l}\text { Qué se en- } \\
\text { tregó }\end{array}$ & $\begin{array}{l}\text { Condiciones } \\
\text { de entrega } \\
\text { y desarrollo } \\
\text { de la unidad } \\
\text { residencial }\end{array}$ & $\begin{array}{l}\text { Equipamientos, infraes- } \\
\text { tructuras en el momen- } \\
\text { to del reasentamiento }\end{array}$ & $\begin{array}{l}\text { Oportu- } \\
\text { nidades } \\
\text { laborales en } \\
\text { el sector en } \\
\text { el momento } \\
\text { del traslado }\end{array}$ & $\begin{array}{l}\text { Acompaña- } \\
\text { miento a la } \\
\text { comunidad } \\
\text { antes del rea- } \\
\text { sentamiento }\end{array}$ & $\begin{array}{l}\text { Acompaña- } \\
\text { miento a la } \\
\text { comunidad } \\
\text { antes del } \\
\text { reasenta- } \\
\text { miento }\end{array}$ & $\begin{array}{l}\text { Problemas de } \\
\text { convivencia, } \\
\text { inseguridad } \\
\text { después del } \\
\text { reasenta- } \\
\text { miento }\end{array}$ \\
\hline $\begin{array}{l}\text { Paraíso } \\
(1987)\end{array}$ & $\begin{array}{l}\text { Sector } \\
\text { poco } \\
\text { consoli- } \\
\text { dado }\end{array}$ & 425 & $\begin{array}{l}\text { Un lote vacío. } \\
\text { Después de } \\
\text { unos años, } \\
\text { el municipio } \\
\text { construye una } \\
\text { unidad básica } \\
\text { en obra negra } \\
\text { con un espa- } \\
\text { cio múltiple y } \\
\text { un baño. }\end{array}$ & $\begin{array}{l}\text { Lote y unidad } \\
\text { básica gratis. } \\
\text { El desarrollo } \\
\text { progresivo de } \\
\text { la unidad con } \\
\text { recursos de la } \\
\text { familia. }\end{array}$ & No & No & No & No & Sí \\
\hline $\begin{array}{l}\text { Yarumales } \\
\text { (1995) }\end{array}$ & $\begin{array}{l}\text { Sector } \\
\text { consoli- } \\
\text { dado }\end{array}$ & 36 & $\begin{array}{l}\text { Una unidad de } \\
55 \mathrm{~m} 2 \text { aproxi- } \\
\text { madamente, } \\
\text { terminada. }\end{array}$ & $\begin{array}{l}\text { Cuota inicial de } \\
600 \text { USD. } \\
\text { Participación } \\
\text { de } 700 \text { horas } \\
\text { en la obra. } \\
\text { Pago de una } \\
\text { cuota mensual } \\
\text { durante } 20 \\
\text { años. Valor } \\
\text { cuota 2010: } 30 \\
\text { USD. }\end{array}$ & $\begin{array}{l}\text { Urbanización al pie de } \\
\text { una avenida y al frente } \\
\text { de un colegio. } \\
\text { Zona de parqueo. } \\
\text { Zonas verdes, parque } \\
\text { infantil, cancha de } \\
\text { deporte. } \\
\text { Transporte público. } \\
\text { Comercio de proxi- } \\
\text { midad. } \\
\text { Iqlesia. }\end{array}$ & $\begin{array}{l}\text { Locales } \\
\text { equipa- } \\
\text { dos para } \\
\text { taller de } \\
\text { modistería, } \\
\text { zapatería y } \\
\text { panadería, } \\
\text { destinados } \\
\text { a la misma } \\
\text { comunidad. }\end{array}$ & $\begin{array}{l}\text { Sí. } \\
\text { Talleres comu- } \\
\text { nitarios sema- } \\
\text { nales durante } \\
\text { dos años. }\end{array}$ & $\begin{array}{l}\text { Sí durante } \\
\text { varios me- } \\
\text { ses. }\end{array}$ & No \\
\hline $\begin{array}{l}\text { Santa Ana } \\
(2005)\end{array}$ & $\begin{array}{l}\text { Periferia } \\
\text { no con- } \\
\text { solidada }\end{array}$ & 392 & $\begin{array}{l}\text { Una unidad de } \\
29 \mathrm{~m} 2 \text { en obra } \\
\text { negra, inclu- } \\
\text { yendo baño } \\
\text { y lavaplatos. } \\
\text { Posibilidad de } \\
\text { ampliación } \\
\text { hasta tres } \\
\text { plantas para } \\
\text { superficie } \\
\text { total de } 72 \mathrm{~m} 2 \text {. }\end{array}$ & $\begin{array}{l}\text { Subsidio } \\
\text { nacional y sub- } \\
\text { sidio municipal } \\
\text { equivalente } \\
\text { al } 60 / 70 \% \text { del } \\
\text { valor del bien. } \\
\text { La parte faltan- } \\
\text { te se financia } \\
\text { a mínimo } 10 \\
\text { años. }\end{array}$ & $\begin{array}{l}\text { Pavimentación de an- } \\
\text { denes y vías internas. } \\
\text { Transporte público. }\end{array}$ & No & No & No & Sí \\
\hline
\end{tabular}

FUENTE: Anne-Catherine Chardon. 


\section{TABLE 1: MULTISCALE CHARACTERISTICS OF RESETTLEMENT}

\begin{tabular}{|c|c|c|c|c|c|c|c|c|c|}
\hline & $\begin{array}{l}\text { Loca- } \\
\text { tion of } \\
\text { the new } \\
\text { area }\end{array}$ & $\begin{array}{l}\text { Re- } \\
\text { settled } \\
\text { families }\end{array}$ & $\begin{array}{l}\text { What was } \\
\text { given }\end{array}$ & $\begin{array}{l}\text { Requirements } \\
\text { and develop of } \\
\text { housing }\end{array}$ & $\begin{array}{l}\text { Amenities and infra- } \\
\text { structure of the new } \\
\text { area }\end{array}$ & $\begin{array}{l}\text { Job oppor- } \\
\text { tunities in } \\
\text { the area at } \\
\text { the moment } \\
\text { of resettling }\end{array}$ & $\begin{array}{l}\text { Support to } \\
\text { families before } \\
\text { resettlement } \\
\text { began }\end{array}$ & $\begin{array}{l}\text { Support } \\
\text { to families } \\
\text { after being } \\
\text { resettled }\end{array}$ & $\begin{array}{l}\text { Coexistence } \\
\text { and insecu- } \\
\text { rity problems } \\
\text { in the new } \\
\text { area }\end{array}$ \\
\hline $\begin{array}{l}\text { El Paraíso } \\
\text { (1987) }\end{array}$ & $\begin{array}{l}\text { Non- } \\
\text { conso- } \\
\text { lidated } \\
\text { area }\end{array}$ & 425 & $\begin{array}{l}\text { Vacant land. } \\
\text { After some } \\
\text { years, the } \\
\text { town council } \\
\text { built basic } \\
\text { housing } \\
\text { consisting } \\
\text { of a multiple } \\
\text { space and a } \\
\text { bathroom }\end{array}$ & $\begin{array}{l}\text { Free land and } \\
\text { basic housing } \\
\text { Progressive } \\
\text { development } \\
\text { of housing } \\
\text { funded by the } \\
\text { proprietary } \\
\text { family }\end{array}$ & No & No & No & No & Yes \\
\hline $\begin{array}{l}\text { Yarumales } \\
\text { (1995) }\end{array}$ & $\begin{array}{l}\text { Conso- } \\
\text { lidated } \\
\text { area }\end{array}$ & 36 & $\begin{array}{l}\text { Completed } \\
55 \mathrm{~m}^{2} \text { housing }\end{array}$ & $\begin{array}{l}\text { Initial payment } \\
\text { of } 600 \text { USD } \\
700 \text { hours of } \\
\text { participation } \\
\text { in the develo- } \\
\text { pment of the } \\
\text { area } \\
\text { Monthly ins- } \\
\text { tallments for } \\
20 \text { years } \\
2010 \text { install- } \\
\text { ment value: } \\
30 \text { SD }\end{array}$ & $\begin{array}{l}\text { Neighborhood located } \\
\text { by the side of an ave- } \\
\text { nue and a school } \\
\text { Parking zone } \\
\text { Green areas, play- } \\
\text { ground, multipurpose } \\
\text { court } \\
\text { Public transport } \\
\text { Local shops } \\
\text { Church }\end{array}$ & $\begin{array}{l}\text { Housing } \\
\text { equipped } \\
\text { to start up } \\
\text { a sewing } \\
\text { workshop, } \\
\text { a cobbler's } \\
\text { workshop } \\
\text { and a } \\
\text { bakery }\end{array}$ & $\begin{array}{l}\text { Yes } \\
\text { Community } \\
\text { workshops } \\
\text { conducted for } \\
\text { two years }\end{array}$ & $\begin{array}{l}\text { Yes } \\
\text { For several } \\
\text { months }\end{array}$ & No \\
\hline $\begin{array}{l}\text { Santa Ana } \\
(2005)\end{array}$ & $\begin{array}{l}\text { Non- } \\
\text { conso- } \\
\text { lidated } \\
\text { peri- } \\
\text { phery }\end{array}$ & 392 & $\begin{array}{l}\text { Basic } 29 \mathrm{~m}^{2} \\
\text { housing, } \\
\text { including } \\
\text { bathroom and } \\
\text { sink }\end{array}$ & $\begin{array}{l}\text { Governmental } \\
\text { and munici- } \\
\text { pal subsidy } \\
\text { covering the } \\
60-70 \% \text { of the } \\
\text { property value }\end{array}$ & $\begin{array}{l}\text { Surfaced sidewalks } \\
\text { and inner ways }\end{array}$ & No & No & No & Yes \\
\hline
\end{tabular}

SOURCE: Anne-Catherine Chardon 
mas se llevan a cabo a nivel de hábitat y muchos no salen de la problemática físico-natural de la ladera.

Estos comentarios desde afuera hacia adentro, sobre las características más importantes de la práctica del reasentamiento, necesitan ser contrastados con la visión propia de los pobladores y entonces, al respecto, se van a relacionar algunos aspectos de la encuesta.

\section{El Hábitat de destino... habla el poblador}

Al $81 \%$ de las personas reasentadas encuestadas, les gusta el sector donde viven, con los más altos porcentajes registrados en las urbanizaciones más antiguas (95\% en El Paraíso y 92\% en Yarumales) y apenas alrededor de un 60\% en las más recientemente construidas. A pesar de esta expresión alta de satisfacción, al 51\% le hubiera gustado ser reubicado en otro sector, para poder vivir más cerca del centro y en un sitio más sano. De manera general, los aspectos buenos de la zona de residencia corresponden a la presencia de vecinos, la tranquilidad/seguridad y el transporte.

En el momento de contestar sobre los aspectos negativos de la urbanización, la gente expresa la inseguridad y la drogadicción. Estos problemas representan un leitmotiv en el discurso de las personas entrevistadas que, apenas en un $26 \%$, comentan on physical-natural problems and few of them take habitat into account.

These comments about the most important characteristics of resettlement are contrasted to the opinion of dwellers in order to link some aspects of the survey.

\section{The Destination Habitat... Comments of Dwellers}

Eighty-one percent of respondents like the area where they live. Old neighborhoods concentrated the highest percentages, 95\% in El Paraiso and 92\% in Yarumales, as for new zones, the approval rate is $60 \%$. Despite this high figure of satisfaction, 51\% of those surveyed would have liked being relocated in another zone in order to live near the downtown, as well as in a healthier environment. Generally, good comments about the zone of residence are related to the presence of neighbors, tranquility/ security and transport.

When asked about the negative aspects of the neighborhoods, respondents mentioned insecurity and addiction to drugs. These problems are the main concern of dwellers, as 
que la seguridad es buena en su barrio, mientras el 39\% lo afirmaba del barrio de origen. La población expresa así que estos indicadores representan condiciones sine qua non de buena calidad de vida, mucho antes que variables posiblemente más evidentes como el empleo o la salud. Además, las cifras muestran que sobre el tema específico de la seguridad, el proceso aun empeoró la situación de origen que inicialmente no era buena.

En cuanto a nivel de equipamiento, servicios y entorno, se evidenció que el sitio de destino presenta una peor situación que la que se comentó para el barrio de origen, a excepción del servicio de transporte (Gráfico 2).

Sin embargo, a pesar de esta pérdida grande en equipamientos, las personas entrevistadas, más allá de gustarles el sector, también comentan en un $78 \%$ que desde que se pasaron al nuevo lugar, su vida cambió y en su mayoría, de manera positiva, principalmente por haber accedido a la propiedad y a vivir sobre un terreno seguro. Importa comentar que de igual manera, se registraron cambios negativos relacionados con la lejanía del sector, la pérdida del empleo, el aumento de los gastos y la inseguridad.

A la escala del elemento fundamental del hábitat para los pobladores, es decir su vivienda, en un $81 \%$ les gusta su casa actual con porcentajes muy inferiores para los habitantes de Santa Ana (67\%), donde los $29 \mathrm{~m}^{2}$ entregados no satisfacen. the $26 \%$ of those surveyed had positive comments about security and the 39\% said security was good in their original neighborhood. In this way, the population expresses that these indicators are essential requirements for ensuring good quality of life, being more important than employment or health aspects. In addition, these figures show that, regarding security, the resettlement process worsened the original situation, which was already bad.

As for amenities, services and environment, the survey showed that, apart from transport, the destination zone has worse characteristics than the original neighborhood. See graphic 2.

However, despite this lack of amenities, the 78\% of respondents said their lives changed after being resettled; to most of them, this change was a positive one, mainly due to the fact of owning a house and living in a safe zone. It is worth commenting that there were also negative changes related to the remoteness of the area, job losses and the increase of expenses and insecurity.

Regarding housing, the fundamental element of habitat, 81\% of dwellers like their current house. This figure drops to 67\% in Santa Ana, where people are not satisfied with their $29 \mathrm{~m}^{2}$ houses. 


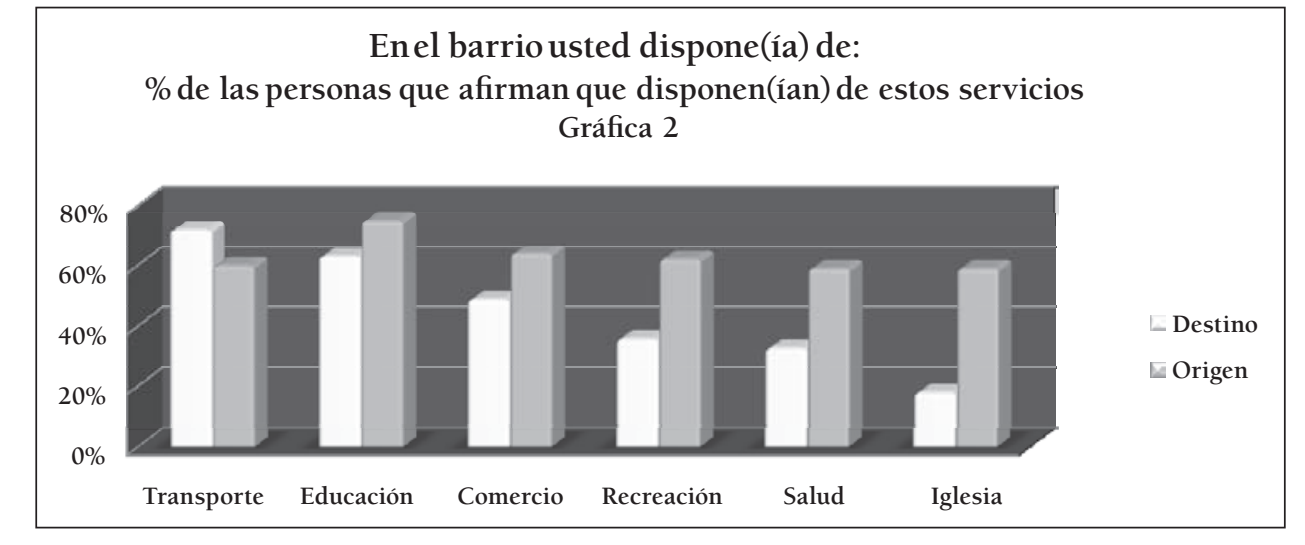

GRÁFICO 2. Fuente: Anne-Catherine Chardon.

GRAPHIC 2. Source: Anne-Catherine Chardon.

En ciertas urbanizaciones, las bonanzas de la casa se deben a factores intrínsecos (amplia, bonita, de material) y en otras, se deben a características extrínsecas (es propiedad de uno, la ubicación), porque las propias de la casa no permitirían valorarla positivamente. En cuanto a los aspectos negativos de la casa, las críticas se dirigen hacia el pequeño tamaño del bien y los problemas de humedad.

Con relación a la vida cotidiana, el ambiente semi rural que se podía observar alrededor de las casas de origen, ya casi no existe, desaparecieron los animales de finca y la presencia de cultivos es insignificante.

Finalmente, a fin de tener la sensación general de las personas con relación al proceso, se quiso saber
In certain areas, as the features of the house itself do not ensure a favorable evaluation, its positive aspects are related either to intrinsic factors (space, beauty, materials), or extrinsic characteristics (it belongs to the dweller, location.) As for the negative aspects, criticism aims at the size of the house and humidity problems.

In relation to daily life, the semi-rural environment observed in the original habitat has almost disappeared, there are no animals and the presence of crops is inconsiderable.

Finally, so as to have the general impressions of dwellers about the process, the survey asked 
si se consideraban beneficiadas o perjudicadas y el 78\% afirmó ser beneficiado por haber podido acceder a la propiedad privada y vivir en una casa sin riesgo. Las personas que estiman ser perjudicadas, principalmente en las urbanizaciones más recientes, argumentan el aumento de los gastos y la estrechez de la casa.

Se puede deducir entonces que, según los pobladores, el agrado relativo hacia el nuevo lugar de vida se debe en gran parte a una resignación porque no tuvieron otra opción de cambio de vida y al logro del gran sueño de las clases media y baja colombianas, ser propietario de un bien en mampostería en un sitio seguro, sin importar el precio socio-cultural por pagar.

\section{Conclusión}

A la luz de los ejemplos comentados, se pudo observar que, en materia de reasentamiento, la praxis está todavía lejos de la teoría que se planteó en un principio y que se puede considerar como válida. Esta situación posiblemente se debe a un desinterés político-administrativo por un real desarrollo sostenible de los pobladores, excepto la preservación de su vida, puesto que se constató que en la mayoría de los aspectos, las personas vivían más acorde con sus hábitos y necesidades antes que después del traslado. Este escenario generalmente conlleva a una adaptación forzosa de las familias reasentadas, a su nuevo lugar de "vida", donde, paulatinamente, people if they felt benefited or affected by resettlement programs; $78 \%$ stated the access to housing and the fact of living in a safe house benefited them. Those who feel affected by the program, mainly people belonging to new neighborhoods, mentioned the increase of expenses and the limited space of the house.

According to the opinion of dwellers, it is inferred that the relative satisfaction about the house is mostly due to resignation, as they did not have another option to choose from, and also because they aim to fulfill the dream of Colombian low and middle classes, which is being the owner of a solid house in a safe zone, regardless of socio-cultural costs.

\section{Conclusion}

In the light of the examples presented in this article, it was observed that regarding resettlement, practical application is far from the theory that is considered valid. This may be due to a lack of political-administrative interest in areas other than preserving the life of dwellers, such as sustainable development, as in most of the aspects, the relationship between people and their habits and needs was higher before resettlement took place. 
tratan de construir un hábitat soportable. En el Paraíso, se demoraron casi dos décadas.

Esta frustración también se observa a través de las expectativas de las personas en cuanto a procesos de reasentamiento, pues la encuesta mostró otros ámbitos de exigencia como una casa grande, agradable, terminada, que no representó gastos adicionales a los acostumbrados, en el marco de un proyecto donde ellas podrían ser actores, esto es participar de las etapas del proceso. El estudio comprobó que la casa es efectivamente el elemento central de un proceso de reasentamiento, tanto en el imaginario de la comunidad como por parte de las instituciones a cargo de los programas.

A nivel institucional particularmente y a través de entrevistas llevadas a cabo con los responsables de las entidades o servicios a cargo de los procesos, se evidenció una visión muy limitada y sesgada del concepto de vulnerabilidad, considerada provocada exclusivamente por factores físico-naturales y físico-espaciales. En ningún momento, los procesos se enmarcan dentro del concepto integral y sistémico de "hábitat", por consiguiente, los proyectos actuales corren el riesgo de no solucionar completamente la situación de vulnerabilidad de la comunidad afectada y además, pueden propiciar la continuidad o la creación de otros factores de vulnerabilidad. Esto significa que en los procesos de reasentamiento, el concepto de vulnerabilidad no solamente se tiene que contemplar como punto de partida, sino tam-
This situation implies the forced adaptation of resettled families to their new place of "life", where they gradually build welcoming habitat. In El Paraíso, it took two decades for people to adapt to their space.

This frustration is also observed in the expectations of people about resettlement programs, as the poll showed requirements such as a bigger, cozy and completed house that does not involve additional costs, within a framework in which dwellers take part in the phases of the process. The survey proved that, to both the community and the institutions in charge of resettlement programs, the house is the central element of this kind of initiatives.

At institutional level, through interviews with the heads of entities in charge of resettlement processes, the concept of vulnerability is limited, biased and caused by physicalnatural and physical-spatial factors. Resettlement processes are not framed within the comprehensive concept of "habitat"; therefore, current projects may not only solve the vulnerability of the affected community but also generate conditions for its continuity or the emergence of new vulnerability factors. This means that resettlement processes should regard vulnerability not only as the starting 
bién como una situación posible a la cual se puede llegar o volver a llegar si el proceso de reasentamiento no se desarrolla de manera adecuada. Por medio de la articulación de los intereses de todos los actores y de una real dialéctica entre los distintos niveles de intervención (unidad habitacional, barrio, ciudad), importa construir una ciudad habitable, tanto desde la urbe como desde la polis.

\section{Bibliografía / Bibliography}

ANDERSON, M; WOODROW, P. Rising from the Ashes: Development Strategies in Times of Desaster. Boulder, Westview Press, 1989

ARIAS V., FELIPE. Castros lucenses de época romana Memorias de Historia Antigua, (8): 7-16, 1987.

BLAIKIE, P., CANNON T., DAVIS I., WISNER, B. Vulnerabilidad. El entorno social, político y económico de los desastres. Bogotá, LA RED/ITDG, 1996

CANNON, T. A Hazard need not a Disaster Make: Rural Vulnerability, and the causes of 'Natural' Disaster", Paper presented at the IBG, Developing Areas Group Conference on Disasters, London, 1991

CEBALLOS R., Olga Lucía Editora Académica. Vivienda Social en Colombia. Una mirada desde su legislación 1918-2005. Editorial Pontificia Universidad Javeriana. 2008. 277 p. ISBN 978-958-716-184-7

CHARDON, ANNE-CATHERINE. Reasentar..., más allá de cuatro muros. Un análisis desde la teoría y point, but also as a possible situation that can be reached several times if the program is not properly implemented. By combining the interests of all participants and through a transversal talk (housing, neighborhood, city), it is important to construct an inhabitable city at local and polis levels.

la praxis del hábitat sostenible. Revista Bitácora Urbano-Territorial, Universidad Nacional de Colombia. 2010, en vía de publicación

----- Amenaza, vulnerabilidad y sociedades urbanas. Una visión desde la dimensión institucional. Revista Gestión y Ambiente, 11(2): 123-136, 2008. ISSN 0124-177X.

------ Un enfoque geográfico de la vulnerabilidad en zonas urbanas expuestas a amenazas naturales. El ejemplo andino de la ciudad de Manizales, Colombia. Manizales, Editorial Centro de Publicaciones Universidad Nacional de Colombia,. 2002. 174 p. ISBN 958-9322-72-7

DRABECK, T. Human System Responses to Disaster: An Inventory of Sociological Findings. New York, Springer Verlag, 1986

DUQUE B., JUAN DAVID. El reasentamiento poblacional: fenómeno social, político y de progreso. 
Revista Estudios Socio-Jurídicos, 8(1): 145-165, enero-julio, 2006. Bogotá, Universidad del Rosario. ISSN 0124-0579

FADDA, GIULIETTA; JIRÓN, PAOLA; BILBA0, MARÍA DE LOS ANGELES. Evaluación de la calidad de vida desde la perspectiva bifocal de 'medio ambiente género'. El caso de un barrio de Santiago. Boletín INVI, 15(39): 121-131, mayo 2000. ISSN 0716-5668.

FLORIÁN B., ALEJANDRO. Algunas reflexiones sobre el derecho a un lugar para vivir y para evolucionar de habitantes a ciudadanos. Bogotá D.C., Colombia, FEDEVIVIENDA. 2002

FRANCO SILVA FRANCISCO JAVIER. Cuerpo, Lugar de vida y Cosmología: Las Dimensiones Culturales del Espacio. BARRIO Taller. La Casa conceptos de Espacio y Vida, Bogotá. 1996. p. 7-30. ISBN 958-9577-717

GARCÍA, JOSÉ LUÍS. Antropología del territorio. Madrid, Taller Edición JB. 1976. 349 p. ISBN 97884-7330-043-8

GIRALDO I., FABIO. Hacia una nueva concepción de la vivienda y el desarrollo urbano. Síntesis del trabajo Necesidades Habitacionales, Informe para el Gerente General del INURBE presentado por el CENAC Bogotá. 1993

GONZÁLES E., LUÍS FERNANDO. La concepción tecnológica del hábitat. En: Miradas al hábitat. Serie de ensayos FORHUM 19. 2002. pp. 21-32 ISBN 958-9126-26-4

74 revista invi № 70 / Noviembre 2010 / Volumen $N^{0} 25:$ 17-75
HEIDEgGER, MARTIN. Construir, Habitar, Pensar. En: Conferencias y artículos. Traducción de Eustaquio Barjau. Barcelona, Serbal. 1994. ISBN 8476281439.

HURTADO I., JUAN GABRIEL. Reasentamiento y habitabilidad. De los asentamientos autogestionados a las soluciones institucionales masivas de vivienda. Estudio de caso, barrio Altos de Santa Ana, comuna Ciudadela del Norte, Manizales. Tesis de Maestría en Hábitat, Universidad Nacional de Colombia, sede Manizales. 2010. 190 p.

LABORDE, PIERRE. Les espaces urbains dans le monde, Nathan Université, 1994, 240 p.

MORENO J., CECILIA INÉS ET AL. Criterios ambientales para la vivienda y el hábitat en el valle de Aburrá. Escuela de Hábitat CEHAP, Universidad Nacional de Colombia Sede Medellín, Centro de Publicaciones. 2005. 171 p. ISBN 9589126294.

OROZCO B., PAULA ANDREA \& GUERRERO CARVAJAL SAIRA INÉS. De la informalidad a la formalidad del hábitat. Proceso de reubicación del barrio La Playita. Trabajo de Grado, Escuela de Arquitectura y Urbanismo, Universidad Nacional de Colombia, sede Manizales. 2008. 93 p.

PARTRIDGE, WILLIAM (EDITOR). Reasentamiento en Colombia. Banco Mundial-Red de Solidaridad Social-ACNUR-Corporación Antioquia Presente, Tercer Mundo Editores. 2000. 338 p.

QUARANTELLI, E.L. Disaster: Theory and Research. Sage Studies in International Sociology, (13) Beverly Hills, California, 1978 
RABINOVICH B., ADRIANA, Participation et architecture : mythes et réalités. Quelques cas d'habitats groupés en Suisse, Thèse doctorale, Ecole Polytechnique Fédérale de Lausane, 1996, 267 p.

RATICK, S. Coping with Climate Change: Vulnerability and Response to Sea level Rise and Severe Storms, Center for Technology, Environment and Development, Clark University, 1994

REPÚBLICA DE COLOMBIA. Constitución Nacional. 1991

ROBLES J., SOLANYI. Impactos del reasentamiento por vulnerabilidad en áreas de alto riesgo. Bogotá 1991-2005. Tesis de Maestría en Hábitat, Universidad Nacional de Colombia, sede Bogotá. 2008. $175 \mathrm{p}$.

SANTOS, MILTON. La naturaleza del espacio. Técnica y tiempo. Razón y emoción. Barcelona, Ariel Geografía. 2000. 348 p. ISBN 84-344-3460-1

TARCHOPOULOS S., DORIS; CEBALLOS RAMOS OLGA

LUCÍA. Calidad de la vivienda dirigida a los sectores de bajos ingresos en Bogotá. Bogotá, CEJA Centro Editorial Javeriano. 2003. 126 p. ISBN 958-683-546-4

YORI, CARLOS MARIO. Topofilia o la dimensión poética del habitar. Segunda edición ampliada, Editorial Pontificia Universidad Javeriana. 2007. 387 p. ISBN 978-958-683-112-4

----- Del espacio ocupado al lugar habitado: una aproximación al concepto de topofilia. 2005. 32 p. 